\title{
Article \\ Antiprotozoal Nor-Triterpene Alkaloids from Buxus sempervirens L.
}

\author{
Lara U. Szabó $^{1}\left(\mathbb{D}\right.$, Marcel Kaiser ${ }^{2,3}$, Pascal Mäser ${ }^{2,3}$ and Thomas J. Schmidt $^{1, *(D)}$ \\ 1 Institute of Pharmaceutical Biology and Phytochemistry (IPBP), University of Münster, \\ PharmaCampus Corrensstraße 48, D-48149 Münster, Germany; lszabo@uni-muenster.de \\ 2 Swiss Tropical and Public Health Institute (Swiss TPH), Socinstrasse 57, CH-4051 Basel, Switzerland; \\ marcel.kaiser@unibas.ch (M.K.); pascal.maeser@swisstph.ch (P.M.) \\ 3 University of Basel, Petersplatz 1, CH-4003 Basel, Switzerland \\ * Correspondence: thomschm@uni-muenster.de; Tel.: +49-251-833-3378
}

Citation: Szabó, L.U.; Kaiser, M.; Mäser, P.; Schmidt, T.J. Antiprotozoal Nor-Triterpene Alkaloids from Buxus sempervirens L. Antibiotics 2021, 10, 696. https://doi.org/10.3390/ antibiotics10060696

Academic Editors: Filippo Maggi and Riccardo Petrelli

Received: 19 May 2021

Accepted: 8 June 2021

Published: 10 June 2021

Publisher's Note: MDPI stays neutral with regard to jurisdictional claims in published maps and institutional affiliations.

Copyright: (c) 2021 by the authors. Licensee MDPI, Basel, Switzerland. This article is an open access article distributed under the terms and conditions of the Creative Commons Attribution (CC BY) license (https:/ / creativecommons.org/licenses/by/ $4.0 /)$.

\begin{abstract}
Malaria and human African trypanosomiasis (HAT; sleeping sickness) are life-threatening tropical diseases caused by protozoan parasites. Due to limited therapeutic options, there is a compelling need for new antiprotozoal agents. In a previous study, O-tigloylcyclovirobuxeine-B was recovered from a B. sempervirens L. (common box; Buxaceae) leaf extract by bioactivity-guided isolation. This nor-cycloartane alkaloid was identified as possessing strong and selective in vitro activity against the causative agent of malaria tropica, Plasmodium falciparum ( $P f)$. The purpose of this study is the isolation of additional alkaloids from $B$. sempervirens L. to search for further related compounds with strong antiprotozoal activity. In conclusion, 25 alkaloids were obtained from $B$. sempervirens L., including eight new natural products and one compound first described for this plant. The structure elucidation was accomplished by UHPLC/+ESI-QqTOF-MS/MS and NMR spectroscopy. The isolated alkaloids were tested against Pf and Trypanosoma brucei rhodesiense (Tbr), the causative agent of East African sleeping sickness. To assess their selectivity, cytotoxicity against mammalian cells (L6 cell line) was tested as well. Several of the compounds displayed promising in vitro activity against the pathogens in a sub-micromolar range with concurrent high selectivity indices (SI). Consequently, various alkaloids from B. sempervirens L. have the potential to serve as a novel antiprotozoal lead structure.
\end{abstract}

Keywords: Buxus sempervirens L.; nor-cycloartane alkaloids; antiprotozoal activity; natural product isolation; structure elucidation

\section{Introduction}

Buxus sempervirens L. (common box; Buxaceae) is an evergreen shrub or small tree, with nor-triterpene alkaloids of the nor-cycloartane type as its main chemical constituents. Decoctions of leaves were ethnopharmacologically used against a variety of indications, including malaria [1,2].

Malaria is a life-threatening infectious disease caused by protozoans of the genus Plasmodium. The vector of these parasites is the infected female Anopheles mosquito. The World Health Organization (WHO) estimated that 229 million malaria cases and 409,000 malaria deaths occurred worldwide in 2019. The incidence has remained virtually unchanged in recent years and, because of the coronavirus pandemic, the WHO estimated 100,000 additional deaths in 2020. The progress in the fight against malaria has stalled. There is a high incidence of treatment failure due to resistance and, thus, the development of new antimalarial drugs is indispensable.

Phytochemical studies on B. sempervirens L. led to the isolation of almost 200 alkaloids [3], which have displayed interesting bioactivities including antibacterial, antimycobacterial, antimalarial, and acetyl- and butyryl-cholinesterase inhibition activity $[4,5]$. 
In a previous study by our group [6], O-tigloylcyclovirobuxeine-B, after bioactivityguided isolation from the dichloromethane extract of $B$. sempervirens leaves, was identified as the constituent mainly responsible for the plant's antiplasmodial activity. It appeared likely that further congeneric alkaloids also yield contributions to the overall antiplasmodial effect of the total leaf extract. Moreover, a lupane triterpene of $B$. sempervirens $L$. showed prominent bioactivity even against drug-resistant malaria parasites [7]. Consequently, the isolation, as well as the antiplasmodial testing of further Buxus-alkaloids, is of great interest.

In a recent study [8], it was determined that the alkaloid-enriched fraction of Pachysandra terminalis (Buxaceae) possessed promising activity against another protozoan parasite, Trypanosoma brucei rhodesiense (Tbr), the causative agent of East African sleeping sickness, a poverty-related neglected tropical disease. This plant contains aminosteroids structurally related to the nor-triterpene alkaloids of $B$. sempervirens L. Furthermore, an isolated compound of $B$. sempervirens $L$., cyclovirobuxeine-B, was found to be highly active and selective against $\mathrm{Tbr}$ in vitro [9]. These findings suggested that additional Buxus-alkaloids could likewise represent strong trypanocides. The chemotherapeutic agents currently in use against African sleeping sickness (human African trypanosomiasis (HAT)) are toxic and have many other associated disadvantages, such as long hospitalization. Accordingly, there is a compelling need for new treatments.

The aim of this study was the identification and characterization of potent and selective antiprotozoal compounds as lead structures against tropical diseases. For this purpose, we report on the systematic isolation of 25 alkaloids from a $B$. sempervirens $L$. leaf extract, including eight new natural products and one compound first described for this plant. The compounds were obtained by centrifugal partition chromatography (CPC), preparative high performance liquid chromatography (prep-HPLC), and column chromatography (CC). Additionally, we present the results of the in vitro testing of the isolated alkaloids against the pathogens of malaria and HAT.

\section{Results and Discussion}

\subsection{Identification of Isolated Buxus-Alkaloids}

The isolation scheme of alkaloids from B. sempervirens L. (Scheme 1) consisted of various separation methods such as CPC, prep-HPLC, and CC. It resulted in the isolation of 25 compounds. The structure elucidation and identification of the isolated Buxus-alkaloids were accomplished by UHPLC/+ESI-QqTOF-MS/MS (henceforth termed "LC/MS") and NMR spectroscopy. Eighteen alkaloids (1-18), with a $9 \beta-19$-cyclo- $5 \alpha$-pregnane core skeleton, were isolated in addition to one steroidal alkaloid (19) and six substances, which possess a $(9(10 \rightarrow 19))$ abeo-5 $\alpha$-pregnane core skeleton (20-25) (Figure 1). The spectral data of the previously known compounds (Table 1), O-tigloylcyclovirobuxeine-B (1) [6,10,11], cyclovirobuxeine-B (2) $[9,12]$, cyclomicrophylline-A (5) $[13,14]$, cyclomicrophyllidine-A (6) [15,16], N-benzoyl-O-acetyl-cycloxo-buxoline-F (9) [10], N-benzoyl-cycloxo-buxoline-F (10) [10], $\mathrm{N}_{\mathrm{b}}$-dimethylcycloxobuxoviricine (12) [17], (E)-cyclobuxophyllinine-M (13) and (Z)-cyclobuxophyllinine-M (14) [18,19], (E)-cyclosuffrobuxinine-M (15) and (Z)-cyclosuffro buxinine-M (16) [20-22], cyclomicrobuxinine (17) [21,23], cyclomicrobuxine (18) [23], irehine (19) [24], 16- $\alpha$-hydroxybuxaminone (20) [25], $\mathrm{N}_{20}$-acetylbuxamine-E (21) [26], and N-benzoyl-O-acetylbuxodienine-E (22) [27], were in full agreement with findings reported in the literature. Additionally, 2D-NMR spectra (COSY, HSQC, and HMBC) were evaluated to confirm the identification of the known compounds. To the best of our knowledge, cyclomicrophyllidine-A (6), previously known only from B. microphylla Sieb. et Zucc., has been isolated from the leaves of $B$. sempervirens $L$. for the first time. 
Table 1. Chemical structures of isolated Buxus-alkaloids 1-25. For core skeletal structures see Figure 1.

\begin{tabular}{|c|c|}
\hline Cpd & Structure \\
\hline & Core skeleton A: \\
\hline 1 & $\mathrm{R}_{1+4}: \mathrm{H}, \mathrm{R}_{2}: \mathrm{N}\left(\mathrm{CH}_{3}\right)_{2}, \mathrm{R}_{3}:\left(\mathrm{CH}_{3}\right)_{2}, \Delta^{6}, \mathrm{R}_{5}:$ O-tiglate, $\mathrm{R}_{6}: \mathrm{NHCH}_{3}$ \\
\hline 2 & $\mathrm{R}_{1+4}: \mathrm{H}, \mathrm{R}_{2}: \mathrm{N}\left(\mathrm{CH}_{3}\right)_{2}, \mathrm{R}_{3}:\left(\mathrm{CH}_{3}\right)_{2}, \Delta^{6}, \mathrm{R}_{5}: \mathrm{OH}, \mathrm{R}_{6}: \mathrm{NHCH}_{3}$ \\
\hline 3 & $\mathrm{R}_{1+4}: \mathrm{H}, \mathrm{R}_{2}: \mathrm{N}\left(\mathrm{CH}_{3}\right)_{2}, \mathrm{R}_{3}: \mathrm{CH}_{3}+\mathrm{CH}_{2} \mathrm{OH}, \Delta^{6}, \mathrm{R}_{5}:$ O-tiglate, $\mathrm{R}_{6}: \mathrm{NHCH}_{3}$ \\
\hline 4 & $\mathrm{R}_{1+4}: \mathrm{H}, \mathrm{R}_{2}: \mathrm{N}\left(\mathrm{CH}_{3}\right)_{2}, \mathrm{R}_{3}: \mathrm{CH}_{3}+\mathrm{CH}_{2} \mathrm{OH}, \Delta^{6}, \mathrm{R}_{5}:$ O-tiglate, $\mathrm{R}_{6}: \mathrm{N}\left(\mathrm{CH}_{3}\right)_{2}$ \\
\hline 5 & $\mathrm{R}_{1+4}: \mathrm{H}, \mathrm{R}_{2}: \mathrm{N}\left(\mathrm{CH}_{3}\right)_{2}, \mathrm{R}_{3}: \mathrm{CH}_{3}+\mathrm{CH}_{2} \mathrm{OH}, \Delta^{6}, \mathrm{R}_{5}: \mathrm{OH}, \mathrm{R}_{6}: \mathrm{N}\left(\mathrm{CH}_{3}\right)_{2}$ \\
\hline 6 & $\mathrm{R}_{1+4}: \mathrm{H}, \mathrm{R}_{2}: \mathrm{N}\left(\mathrm{CH}_{3}\right)_{2}, \mathrm{R}_{3}: \mathrm{CH}_{3}+\mathrm{CH}_{2} \mathrm{OH}, \Delta^{6}, \mathrm{R}_{5}:$ O-benzoate, $\mathrm{R}_{6}: \mathrm{N}\left(\mathrm{CH}_{3}\right)_{2}$ \\
\hline 7 & $\mathrm{R}_{1+4}: \mathrm{H}, \mathrm{R}_{2}: \mathrm{N}\left(\mathrm{CH}_{3}\right)_{2}, \mathrm{R}_{3}: \mathrm{CH}_{3}+\mathrm{CH}_{2} \mathrm{OH}, \Delta^{6}, \mathrm{R}_{5}:$ O-benzoate, $\mathrm{R}_{6}: \mathrm{NHCH}_{3}$ \\
\hline 8 & $\mathrm{R}_{1}:$ O-benzoate, $\mathrm{R}_{2}: \mathrm{NHCH}_{3}, \mathrm{R}_{3}:\left(\mathrm{CH}_{3}\right)_{2}, \mathrm{R}_{4+5}: \mathrm{H}, \mathrm{R}_{6}: \mathrm{NHCH}_{3}$ \\
\hline 9 & $\mathrm{R}_{1+5}: \mathrm{H}, \mathrm{R}_{2}:$ benzamide, $\mathrm{R}_{3}: \mathrm{CH}_{3}+\mathrm{CH}_{2} \mathrm{OAc}, \mathrm{R}_{4}:=\mathrm{O}, \mathrm{R}_{6}: \mathrm{N}\left(\mathrm{CH}_{3}\right)_{2}$ \\
\hline 10 & $\mathrm{R}_{1+5}: \mathrm{H}, \mathrm{R}_{2}$ : benzamide, $\mathrm{R}_{3}: \mathrm{CH}_{3}+\mathrm{CH}_{2} \mathrm{OH}, \mathrm{R}_{4}:=\mathrm{O}, \mathrm{R}_{6}: \mathrm{N}\left(\mathrm{CH}_{3}\right)_{2}$ \\
\hline 11 & $\mathrm{R}_{1+4}: \mathrm{H}, \mathrm{R}_{2}:=\mathrm{O}, \mathrm{R}_{3}: \mathrm{CH}_{3}+\mathrm{CH}_{2} \mathrm{OH}, \mathrm{R}_{5}: \mathrm{OH}, \mathrm{R}_{6}: \mathrm{N}\left(\mathrm{CH}_{3}\right)_{2}$ \\
\hline 12 & $\mathrm{R}_{1+4}: \mathrm{H}, \Delta^{1,2}, \mathrm{R}_{2}:=\mathrm{O}, \mathrm{R}_{3}:\left(\mathrm{CH}_{3}\right)_{2}, \mathrm{R}_{5}: \mathrm{OH}, \mathrm{R}_{6}: \mathrm{N}\left(\mathrm{CH}_{3}\right)_{2}$ \\
\hline 13 & $\mathrm{R}_{1+4+6}: \mathrm{H}, \mathrm{R}_{2}: \mathrm{NHCH}_{3}, \mathrm{R}_{3}:\left(\mathrm{CH}_{3}\right)_{2}, \mathrm{R}_{5}:=\mathrm{O}, \Delta^{17(20)}(E)$ \\
\hline 14 & $\mathrm{R}_{1+4+6}: \mathrm{H}, \mathrm{R}_{2}: \mathrm{NHCH}_{3}, \mathrm{R}_{3}:\left(\mathrm{CH}_{3}\right)_{2}, \mathrm{R}_{5}:=\mathrm{O}, \Delta^{17(20)}(\mathrm{Z})$ \\
\hline 15 & $\mathrm{R}_{1+4+6}: \mathrm{H}, \mathrm{R}_{2}: \mathrm{NHCH}_{3}, \mathrm{R}_{3}:=\mathrm{CH}_{2}, \mathrm{R}_{5}:=\mathrm{O}, \Delta^{17(20)}(E)$ \\
\hline 16 & $\mathrm{R}_{1+4+6}: \mathrm{H}, \mathrm{R}_{2}: \mathrm{NHCH}_{3}, \mathrm{R}_{3}:=\mathrm{CH}_{2}, \mathrm{R}_{5}:=\mathrm{O}, \Delta^{17(20)}(\mathrm{Z})$ \\
\hline 17 & $\mathrm{R}_{1+4}: \mathrm{H}, \mathrm{R}_{2}: \mathrm{NHCH}_{3}, \mathrm{R}_{3}:=\mathrm{CH}_{2}, \mathrm{R}_{5}: \mathrm{OH}, \mathrm{R}_{6}:=\mathrm{O}$ \\
\hline \multirow[t]{2}{*}{18} & $\mathrm{R}_{1+4}: \mathrm{H}_{1} \mathrm{R}_{2}: \mathrm{N}\left(\mathrm{CH}_{3}\right)_{2}, \mathrm{R}_{3}:=\mathrm{CH}_{2}, \mathrm{R}_{5}: \mathrm{OH}, \mathrm{R}_{6}:=\mathrm{O}$ \\
\hline & Core skeleton $\mathbf{B}$ : \\
\hline \multirow[t]{2}{*}{19} & $\mathrm{R}_{1}: \mathrm{OH}, \mathrm{R}_{2}: \mathrm{N}\left(\mathrm{CH}_{3}\right)_{2}$ \\
\hline & Core skeleton C: \\
\hline 20 & $\mathrm{R}_{1}: \mathrm{N}\left(\mathrm{CH}_{3}\right)_{2}, \mathrm{R}_{2}: \mathrm{OH}, \mathrm{R}_{3}: \mathrm{H}, \mathrm{R}_{4}:=\mathrm{O}$ \\
\hline 21 & $\mathrm{R}_{1}: \mathrm{N}\left(\mathrm{CH}_{3}\right)_{2}, \mathrm{R}_{2+3}: \mathrm{H}, \mathrm{R}_{4}: \mathrm{NHAc}$ \\
\hline 22 & $\mathrm{R}_{1}: \mathrm{N}\left(\mathrm{CH}_{3}\right)_{2}, \mathrm{R}_{2}: \mathrm{OAc}, \mathrm{R}_{3}: \mathrm{H}, \mathrm{R}_{4}$ : benzamide \\
\hline 23 & $\mathrm{R}_{1}: \mathrm{N}\left(\mathrm{CH}_{3}\right)_{2}, \mathrm{R}_{2}: \mathrm{OAc}, \mathrm{R}_{3}: \mathrm{H}, \mathrm{R}_{4}$ : benzamide \\
\hline 24 & $\mathrm{R}_{1}: \mathrm{NHCH}_{3}, \mathrm{R}_{2+3}: \mathrm{H}, \mathrm{R}_{4}: \mathrm{NHAc}$ \\
\hline 25 & $\mathrm{R}_{1}: \mathrm{NHCH}_{3}, \mathrm{R}_{2}: \mathrm{H}, \mathrm{R}_{3+4}: \mathrm{OH}$ \\
\hline
\end{tabular}

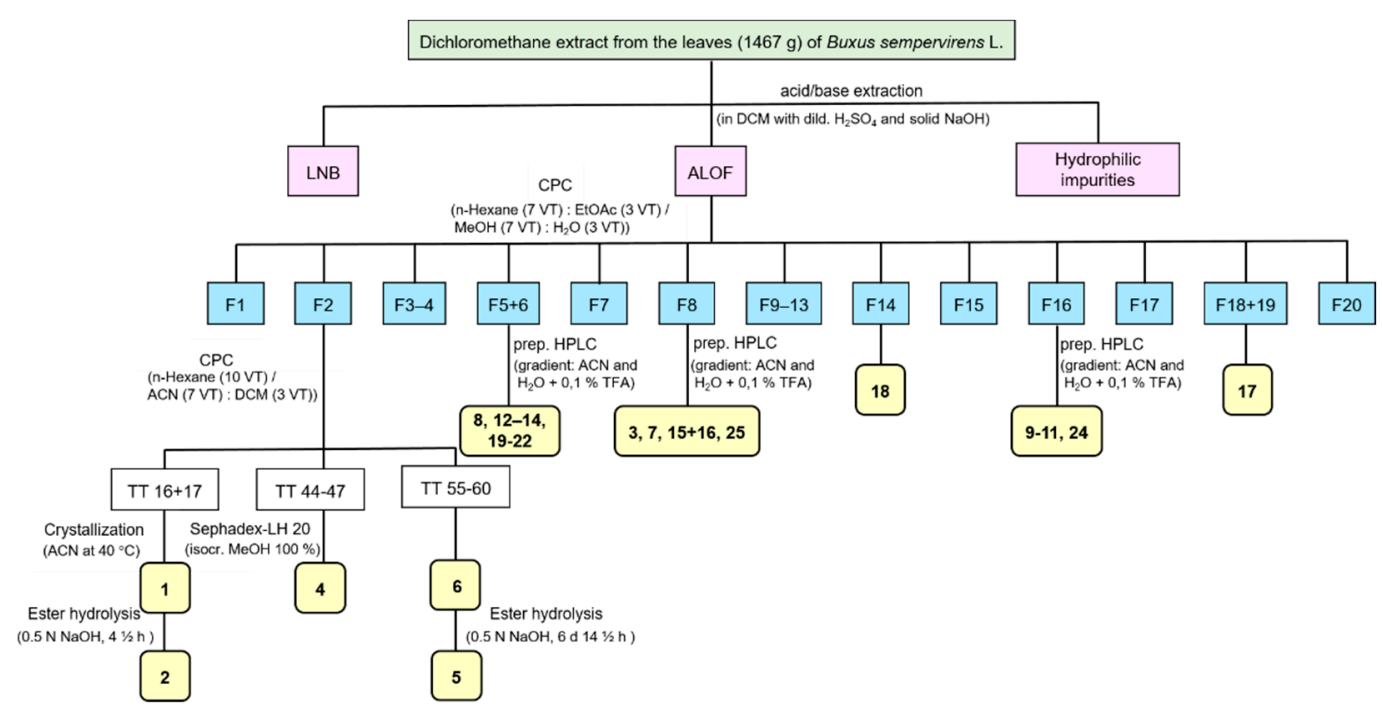

Scheme 1. From the leaves of B. sempervirens L. Abbreviations: lipophilic and neutral fraction (LNB); alkaloid fraction (ALOF); centrifugal partition chromatography (CPC); fraction (F); and test tube (TT). 


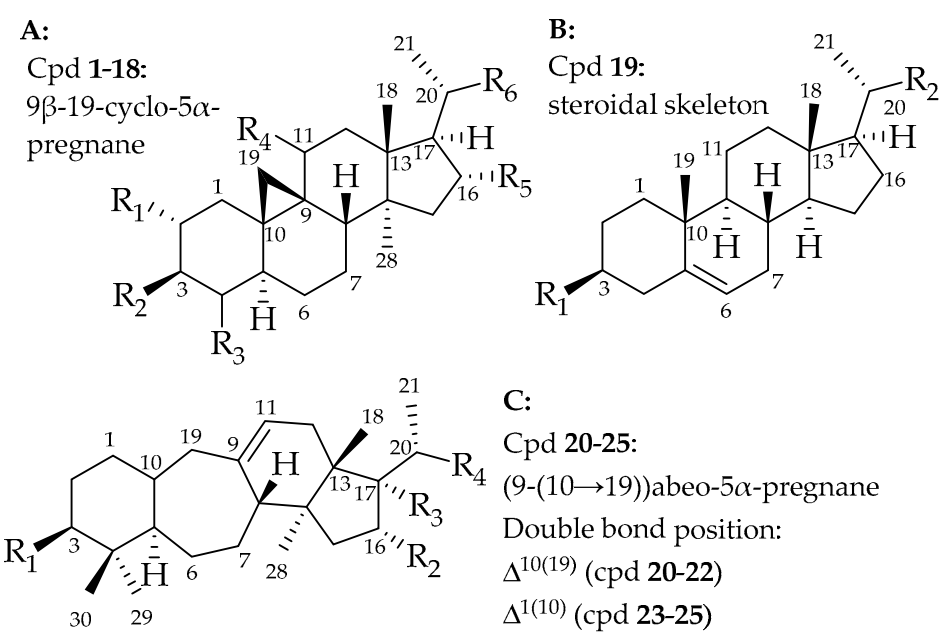

Figure 1. Core skeletons of isolated Buxus-alkaloids 1-25. For complete structures, see Table 1.

The eight compounds $3,4,7,8, \mathbf{1 1}$, and 23-25 are described for the first time, to the best of our knowledge.

The molecular formula of compound 3, obtained as a colorless gum, was determined as $\mathrm{C}_{32} \mathrm{H}_{52} \mathrm{~N}_{2} \mathrm{O}_{3}$ by LC/MS (Figures S5-S7, Supplementary Materials). The ${ }^{1} \mathrm{H}$ - and ${ }^{13} \mathrm{C}$ NMR spectroscopic data (Table 2; Figures S8-S17, Supplementary Materials) displayed partly similar signals to 1 and differed from $9 \beta-19$-cyclo-5 $\alpha$-pregnane by the presence of signals for a methylene instead of a methyl group. The chemical shift of the methylene $\left(\delta_{\mathrm{C}}=67.80 ; \delta_{\mathrm{H}}=4.05\right.$ and $\left.3.79(1 \mathrm{H}, \mathrm{d}, 11.6 \mathrm{~Hz})\right)$ suggested a hydroxyl-containing structure $\mathrm{HMBC}$ correlations of the methylene carbon with $\mathrm{H}-3, \mathrm{H}-5, \mathrm{H}-8$ and $\mathrm{H}-30$ confirmed compound 3 as the C-29 hydroxylated analogue of $\mathbf{1}$ (Figure 2). 
Table 2. ${ }^{1} \mathrm{H}$ - and ${ }^{13} \mathrm{C}-\mathrm{NMR}$ data of compounds $3\left(600 / 150 \mathrm{MHz}, \mathrm{CDCl}_{3}\right), 4,7$ and $8\left(600 / 150 \mathrm{MHz}, \mathrm{CD}_{3} \mathrm{OD}\right)$.

\begin{tabular}{|c|c|c|c|c|c|c|c|c|}
\hline \multirow[b]{2}{*}{ Pos. } & \multicolumn{2}{|r|}{3} & \multicolumn{2}{|r|}{4} & \multicolumn{2}{|r|}{7} & \multicolumn{2}{|c|}{8} \\
\hline & $\delta_{C}[p p m]$ & $\begin{array}{c}\delta_{\mathrm{H}}[\mathrm{ppm}], \text { mult., } \mathrm{J} \\
{[\mathrm{Hz}]}\end{array}$ & $\delta_{C}[p p m]$ & $\begin{array}{c}\delta_{\mathrm{H}}[\mathrm{ppm}], \text { mult., } \mathrm{J} \\
{[\mathrm{Hz}]}\end{array}$ & $\delta_{C}[p p m]$ & $\begin{array}{c}\delta_{H}[p p m], \text { mult., } J \\
{[\mathrm{~Hz}]}\end{array}$ & $\delta_{C}[p p m]$ & $\begin{array}{c}\left.\delta_{H}[p p m], \text { mult., }\right] \\
{[\mathrm{Hz}]}\end{array}$ \\
\hline 1 & $29.82, \mathrm{CH}_{2}$ & $\begin{array}{c}1.74, \mathrm{~d}, 12.4 \\
1.69, \mathrm{~m} \\
\end{array}$ & $31.72, \mathrm{CH}_{2}$ & $1.63, \mathrm{~m}(2 \mathrm{H})$ & $30.44, \mathrm{CH}_{2}$ & $1.75, \mathrm{~m}(2 \mathrm{H})$ & $38.75, \mathrm{CH}_{2}$ & $\begin{array}{c}1.98, \mathrm{dd}, 12.5,4.9 \\
1.79, \mathrm{~m}\end{array}$ \\
\hline 2 & $20.01, \mathrm{CH}_{2}$ & $\begin{array}{l}1.96, \mathrm{~m} \\
1.87, \mathrm{~m}\end{array}$ & $19.62, \mathrm{CH}_{2}$ & $\begin{array}{l}1.82, \mathrm{~m} \\
1.68, \mathrm{~m}\end{array}$ & $20.94, \mathrm{CH}_{2}$ & $\begin{array}{c}2.07, \mathrm{dd}, 12.5,3.5 \\
1.92, \mathrm{~m}\end{array}$ & $74.49, \mathrm{CH}$ & $5.30, \mathrm{td}, 10.9,4.8$ \\
\hline 3 & $72.94, \mathrm{CH}$ & $3.46, \mathrm{dd}, 12.8,3.5$ & $73.29, \mathrm{CH}$ & $2.71, \mathrm{dd}, 12.3,3.4$ & $75.62, \mathrm{CH}$ & $3.49, \mathrm{~m}$ & $73.20, \mathrm{CH}$ & $3.35, \mathrm{~d}, 11.0$ \\
\hline 4 & $42.69, \mathrm{qC}$ & - & $43.36, \mathrm{qC}$ & - & $43.21, \mathrm{qC}$ & - & $41.53, \mathrm{qC}$ & - \\
\hline 6 & $125.03, \mathrm{CH}$ & $5.54, d, 10.8$ & $126.72, \mathrm{CH}$ & $5.49, \mathrm{~m}$ & $126.06, \mathrm{CH}$ & $5.52, \mathrm{~m}$ & $21.93, \mathrm{CH}_{2}$ & $\begin{array}{l}1.77, \mathrm{~m} \\
0.94, \mathrm{~m}\end{array}$ \\
\hline 7 & $129.83, \mathrm{CH}$ & 5.50, ddd, $10.8,5.8,2.8$ & $130.42, \mathrm{CH}$ & 5.45, ddd, 10.6, 5.8, 2.9 & $130.96, \mathrm{CH}$ & $5.56, \mathrm{~m}$ & $26.75, \mathrm{CH}_{2}$ & $\begin{array}{l}1.47, \mathrm{~m} \\
1.23, \mathrm{~m}\end{array}$ \\
\hline 8 & $42.71, \mathrm{CH}$ & $2.65, \mathrm{~m}$ & $44.49, \mathrm{CH}$ & $2.63, \mathrm{~m}$ & $44.05, \mathrm{CH}$ & $2.74, \mathrm{~m}$ & $48.95, \mathrm{CH}$ & $1.66, \mathrm{dd}, 12.5,4.8$ \\
\hline 9 & $20.74, \mathrm{qC}$ & - & $21.72, \mathrm{qC}$ & - & $21.80, \mathrm{qC}$ & - & $20.91, \mathrm{qC}$ & - \\
\hline 10 & $27.32, \mathrm{qC}$ & - & $29.07, \mathrm{qC}$ & - & $28.55, \mathrm{qC}$ & - & $25.47, \mathrm{qC}$ & - \\
\hline 11 & $24.83, \mathrm{CH}_{2}$ & $\begin{array}{c}1.90, \mathrm{dd}, 14.6,4.7 \\
1.46, \mathrm{~m}\end{array}$ & $26.07, \mathrm{CH}_{2}$ & $\begin{array}{l}1.90, \mathrm{~m} \\
1.51, \mathrm{~m}\end{array}$ & $25.74, \mathrm{CH}_{2}$ & $\begin{array}{l}1.99, \mathrm{~m} \\
1.58, \mathrm{~m}\end{array}$ & $27.10, \mathrm{CH}_{2}$ & $\begin{array}{l}2.11, \mathrm{~m} \\
1.22, \mathrm{~m}\end{array}$ \\
\hline 13 & $47.53, \mathrm{qC}$ & - & $46.27, \mathrm{qC}$ & - & $47.88, \mathrm{qC}$ & - & $46.89, \mathrm{qC}$ & - \\
\hline 14 & $49.48, \mathrm{qC}$ & - & $50.79, \mathrm{qC}$ & - & $50.35, \mathrm{qC}$ & - & $50.04, \mathrm{qC}$ & - \\
\hline 15 & $42.33, \mathrm{CH}_{2}$ & $\begin{array}{l}2.16, \mathrm{~m} \\
1.44, \mathrm{~m}\end{array}$ & $43.28, \mathrm{CH}_{2}$ & $\begin{array}{c}2.08, \mathrm{~m} \\
1.11, \mathrm{~d}, 13.9\end{array}$ & $43.59, \mathrm{CH}_{2}$ & $\begin{array}{l}2.39, \mathrm{dd}, 14.7,8.7 \\
1.46, \mathrm{dd}, 14.6,1.2\end{array}$ & $36.46, \mathrm{CH}_{2}$ & $\begin{array}{l}1.56, \mathrm{~m} \\
1.52, \mathrm{~m}\end{array}$ \\
\hline 16 & $78.68, \mathrm{CH}$ & $5.26, \mathrm{dd}, 8.3,5.5$ & $81.26, \mathrm{CH}$ & 5.12, ddd $, 8.5,5.9,1.0$ & $80.89, \mathrm{CH}$ & 5.28, ddd $, 8.3,6.4,1.3$ & $27.01, \mathrm{CH}_{2}$ & $\begin{array}{l}2.02, \mathrm{~m} \\
1.58, \mathrm{~m}\end{array}$ \\
\hline 17 & $55.41, \mathrm{CH}$ & $2.46, \mathrm{dd}, 10.8,5.5$ & $56.84, \mathrm{CH}$ & $2.21, \mathrm{~m}$ & $55.65, \mathrm{CH}$ & $2.58, \mathrm{dd}, 10.8,6.3$ & $51.04, \mathrm{CH}$ & $2.06, \mathrm{~m}$ \\
\hline 18 & $15.77, \mathrm{CH}_{3}$ & $1.04, \mathrm{~s}$ & $16.28, \mathrm{CH}_{3}$ & $1.00, \mathrm{~s}$ & $15.91, \mathrm{CH}_{3}$ & $1.13, \mathrm{~s}$ & $18.68, \mathrm{CH}_{3}$ & $1.08, \mathrm{~s}$ \\
\hline 19 & $17.94, \mathrm{CH}_{2}$ & $\begin{array}{c}0.83, \mathrm{~d}, 4.4 \\
-0.03, \mathrm{~d}, 4.4 \\
\end{array}$ & $19.09, \mathrm{CH}_{2}$ & $\begin{array}{c}0.79, \mathrm{~d}, 4.1 \\
-0.07, \mathrm{~d}, 4.2 \\
\end{array}$ & $18.61, \mathrm{CH}_{2}$ & $\begin{array}{l}0.85, \mathrm{~d}, 4.3 \\
0.08, \mathrm{~d}, 4.5 \\
\end{array}$ & $30.11, \mathrm{CH}_{2}$ & $\begin{array}{l}0.80, \mathrm{~d}, 4.6 \\
0.71, \mathrm{~d}, 4.6 \\
\end{array}$ \\
\hline 20 & $57.14, \mathrm{CH}$ & $3.41, \mathrm{~m}$ & $61.37, \mathrm{CH}$ & $2.63, \mathrm{~m}$ & $58.42, \mathrm{CH}$ & $3.58, \mathrm{~m}$ & $60.44, \mathrm{CH}$ & $3.24, \mathrm{~m}$ \\
\hline 21 & $15.45, \mathrm{CH}_{3}$ & $1.41, \mathrm{~d}, 6.5$ & $10.53, \mathrm{CH}_{3}$ & $0.89, \mathrm{~d}, 6.4$ & $15.54, \mathrm{CH}_{3}$ & $1.41, \mathrm{~d}, 6.5$ & $15.45, \mathrm{CH}_{3}$ & $1.31, \mathrm{~d}, 6.4$ \\
\hline 28 & $17.45, \mathrm{CH}_{3}$ & $0.98, \mathrm{~s}$ & $18.16, \mathrm{CH}_{3}$ & $0.98, \mathrm{~s}$ & $18.46, \mathrm{CH}_{3}$ & $1.04, \mathrm{~s}$ & $19.71, \mathrm{CH}_{3}$ & $1.01, \mathrm{~s}$ \\
\hline 29 & $67.80, \mathrm{CH}_{2}$ & $\begin{array}{l}4.05, d, 11.6 \\
3.79, d, 11.5 \\
\end{array}$ & $72.91, \mathrm{CH}_{2}$ & $\begin{array}{l}3.81, d, 10.4 \\
3.52, d, 10.3 \\
\end{array}$ & $70.91, \mathrm{CH}_{2}$ & $\begin{array}{l}3.92, \mathrm{~m} \\
3.65, \mathrm{~m} \\
\end{array}$ & $25.16, \mathrm{CH}_{3}$ & $1.20, \mathrm{~s}$ \\
\hline
\end{tabular}


Table 2. Cont.

\begin{tabular}{|c|c|c|c|c|c|c|c|c|}
\hline \multirow[b]{2}{*}{ Pos. } & \multicolumn{2}{|c|}{3} & \multicolumn{2}{|c|}{4} & \multicolumn{2}{|c|}{7} & \multicolumn{2}{|c|}{8} \\
\hline & $\delta_{C}[p p m]$ & $\begin{array}{c}\delta_{\mathbf{H}}[\mathrm{ppm}], \text { mult., J } \\
{[\mathrm{Hz}]}\end{array}$ & $\delta_{C}[p p m]$ & $\begin{array}{c}\delta_{\mathrm{H}}[\mathrm{pppm}], \text { mult., } \mathrm{J} \\
{[\mathrm{Hz}]}\end{array}$ & $\delta_{C}[p p m]$ & $\begin{array}{c}\delta_{\mathbf{H}}[\mathrm{ppm}], \text { mult., J } \\
{[\mathrm{Hz}]}\end{array}$ & $\delta_{C}[p p m]$ & $\begin{array}{c}\delta_{\mathbf{H}}[\mathrm{ppm}], \text { mult., } \mathrm{J} \\
{[\mathrm{Hz}]}\end{array}$ \\
\hline 30 & $12.89, \mathrm{CH}_{3}$ & $1.10, \mathrm{~s}$ & $12.78, \mathrm{CH}_{3}$ & $1.05, \mathrm{~s}$ & $12.31, \mathrm{CH}_{3}$ & $1.14, \mathrm{~s}$ & $15.76, \mathrm{CH}_{3}$ & $1.06, \mathrm{~s}$ \\
\hline \multirow[t]{2}{*}{$31 / 32$} & $45.64, \mathrm{CH}_{3}$ & $2.96, \mathrm{~s}(3 \mathrm{H})$ & $42.94, \mathrm{CH}_{3}$ & $2.37, \mathrm{~s}(6 \mathrm{H})$ & $45.40, \mathrm{CH}_{3}$ & $2.94, \mathrm{~s}(3 \mathrm{H})$ & $37.69, \mathrm{CH}_{3}$ & $2.96, \mathrm{~s}(3 \mathrm{H})$ \\
\hline & $39.09, \mathrm{CH}_{3}$ & $2.77, \mathrm{~s}(3 \mathrm{H})$ & & & $39.31, \mathrm{CH}_{3}$ & $2.78, \mathrm{~s}(3 \mathrm{H})$ & & \\
\hline $33 / 34$ & $29.06, \mathrm{CH}_{3}$ & $2.66, \mathrm{~s}(3 \mathrm{H})$ & $40.71, \mathrm{CH}_{3}$ & $2.14, \mathrm{~s}(6 \mathrm{H})$ & $30.01, \mathrm{CH}_{3}$ & $2.69, \mathrm{~s}(3 \mathrm{H})$ & $29.88, \mathrm{CH}_{3}$ & $2.67, \mathrm{~s}(3 \mathrm{H})$ \\
\hline $\mathrm{OCO}$ & & & & & $167.54, \mathrm{qC}$ & - & $166.74, \mathrm{qC}$ & - \\
\hline $1^{\prime}$ & $169.61, \mathrm{qC}$ & - & 169.27, qC & - & $131.45, \mathrm{qC}$ & - & $130.97, \mathrm{qC}$ & - \\
\hline $3^{\prime}$ & $141.17, \mathrm{CH}$ & $6.91, \mathrm{qq}, 7.0,1.4$ & $137.75, \mathrm{CH}$ & $6.80, \mathrm{qq}, 7.0,1.3$ & $129.76, \mathrm{CH}$ & $7.50, \mathrm{~m}$ & $129.95, \mathrm{CH}$ & $7.53, \mathrm{~m}$ \\
\hline $4^{\prime}$ & $14.81, \mathrm{CH}_{3}$ & $1.81, \mathrm{~m}$ & $14.31, \mathrm{CH}_{3}$ & $1.79, \mathrm{~m}$ & $134.55, \mathrm{CH}$ & $7.63, \mathrm{~m}$ & $134.86, \mathrm{CH}$ & $7.66, \mathrm{~m}$ \\
\hline $5^{\prime}$ & $11.90, \mathrm{CH}_{3}$ & $1.80, \mathrm{~m}$ & $12.16, \mathrm{CH}_{3}$ & $1.81, \mathrm{~m}$ & $129.76, \mathrm{CH}$ & $7.50, \mathrm{~m}$ & $129.95, \mathrm{CH}$ & $7.53, \mathrm{~m}$ \\
\hline $6^{\prime}$ & & & & & $130.48, \mathrm{CH}$ & $8.03, \mathrm{~m}$ & $130.53, \mathrm{CH}$ & $8.06, \mathrm{~m}$ \\
\hline
\end{tabular}




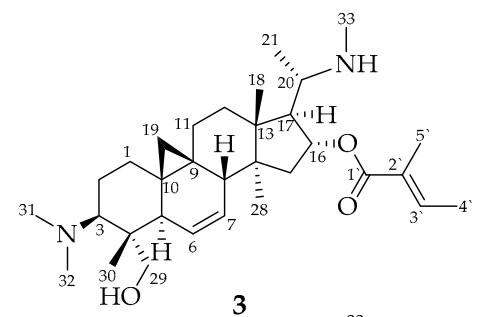

(1)
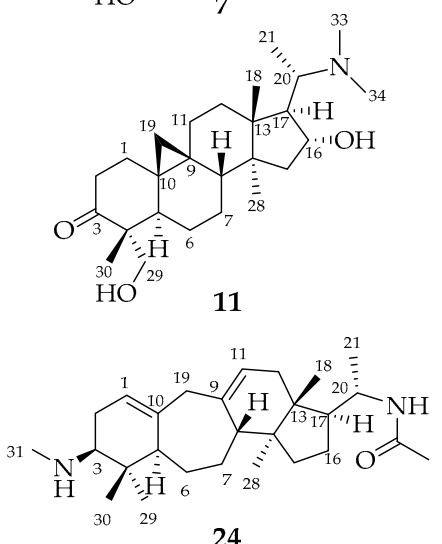

24
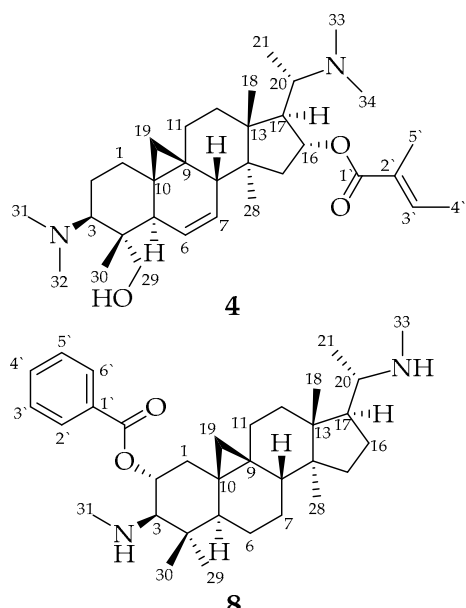

8
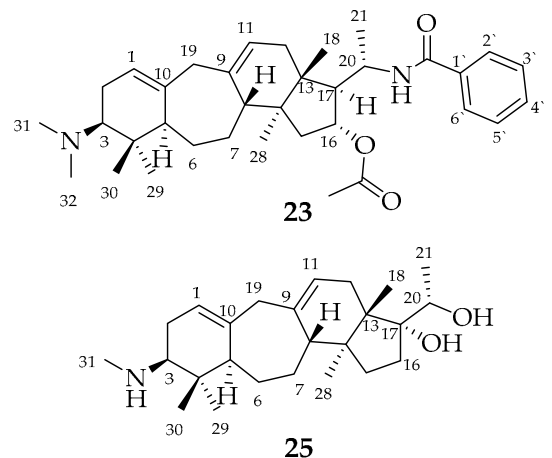

25

Figure 2. Chemical structure of the new natural products 3, 4, 7, 8, 11 and 23-25.

Compound 4, obtained from CPC fraction 2 as a white powder, possesses the molecular formula $\mathrm{C}_{33} \mathrm{H}_{54} \mathrm{~N}_{2} \mathrm{O}_{3}$ according to LC/MS analysis (Figures S18-S20, Supplementary Materials), which indicates a further methylated analogue of 3 . The ${ }^{1} \mathrm{H}-$ and ${ }^{13} \mathrm{C}-\mathrm{NMR}$ spectroscopic data (Table 2; Figures S21-S30, Supplementary Materials) displayed great similarity between 4 and 3 . In contrast to a monomethylated amine in 3, 4 displayed signals of two magnetically equivalent $\mathrm{N}$-methyl groups at $\delta_{\mathrm{C}}=40.71$ and $\delta_{\mathrm{H}}=2.14(6 \mathrm{H}$, s), which showed correlation with C-20 in the HMBC experiment. In contrast to compound 3, the structure of 4 possesses a tertiary amine (dimethylamino group) at position C-20 instead of a secondary amine (monomethylamino group) (Figure 2).

For compound 7 , the molecular formula was determined as $\mathrm{C}_{34} \mathrm{H}_{50} \mathrm{~N}_{2} \mathrm{O}_{3}$ by LC/MS (Figures S39-S41, Supplementary Materials). Most signals in the NMR spectra (Table 2; Figures S42-S50, Supplementary Materials) were in common with compound 3 . The only difference was observed in the signals of the ester side chain at C-16 of 7, which differed from 3 by the presence of a benzoate moiety instead of a tiglate moiety (Figure 2).

Compound 8, isolated from CPC fractions 5 and 6, displayed the molecular formula $\mathrm{C}_{33} \mathrm{H}_{50} \mathrm{~N}_{2} \mathrm{O}_{2}$ in LC/MS analysis (Figures S51-S53, Supplementary Materials). The signals of the NMR spectra (Table 2; Figures S54-S62, Supplementary Materials) for the major part were in agreement with the previous $9 \beta-19$-cyclo- $5 \alpha$-pregnane derivatives (1-7). In the ${ }^{1} \mathrm{H}-\mathrm{NMR}$ spectrum the two doublet signals $(\mathrm{J}=4.6 \mathrm{~Hz})$ of the methylene group at $\mathrm{C}-19$ of the cyclopropane ring could be detected at $\delta_{\mathrm{H}}=0.80$ and 0.71 . This downfield shift in comparison to the corresponding signal in compounds 1-7, which all display the signal for one of the protons at $\mathrm{C}-19$ between $\delta_{\mathrm{H}}=0.4$ and -0.2 , indicates the absence of anisotropic shielding by the $\Delta^{6}$ double bond. This observation was in full agreement with the absence of an olefinic proton signal for position 6 and so, in conclusion, the B-ring in $\mathbf{8}$ is fully saturated $[17,28]$. In addition, the typical proton signals of a benzoic acid ester at $\delta_{\mathrm{H}}=8.06$ $\left(\mathrm{m}(2 \mathrm{H})\right.$, Pos. $\left.2^{\prime} / 6^{\prime}\right), 7.66\left(\mathrm{~m}(1 \mathrm{H})\right.$, Pos. $\left.4^{\prime}\right)$, and $7.53\left(\mathrm{~m}(2 \mathrm{H})\right.$, Pos $\left.3^{\prime} / 5^{\prime}\right)$ could be identified. 
The carbonyl carbon of the ester resonated at $\delta_{\mathrm{C}}=166.74$ and showed ${ }^{3} \mathrm{~J}$ couplings in the ${ }^{1} \mathrm{H} /{ }^{13} \mathrm{C}-\mathrm{HMBC}$ spectrum with the protons in position 2 of the A-ring and positions $2^{\prime} / 6^{\prime}$ of the benzoic acid. The proton in position 2, accordingly, displayed the usual chemical shift caused by geminal relationship with an ester group, i.e., $\delta_{\mathrm{H}}=5.30(\operatorname{td}(1 \mathrm{H}), \mathrm{J}=10.9$ and $4.8 \mathrm{~Hz})$ [29]. The signals at $\delta_{\mathrm{H}}=2.96(\mathrm{~s}(3 \mathrm{H}))$ and $2.67(\mathrm{~s}(3 \mathrm{H}))$ indicated a Buxusalkaloid with two monomethylated amino groups at C-3 and C-20. The resulting structure is presented in Figure 2.

For compound 11, the molecular formula was determined as $\mathrm{C}_{26} \mathrm{H}_{43} \mathrm{NO}_{3}$ by $\mathrm{LC} / \mathrm{MS}$ (Figures S71-S73, Supplementary Materials). In the ${ }^{1} \mathrm{H},{ }^{13} \mathrm{C}$, and HSQC-NMR spectra for 11 (Table 2; Figures S74-S81, Supplementary Materials) the presence of six $\mathrm{sp}^{3}$ quaternary carbons, five methines, nine methylenes, and six methyl groups were detected. The present compound showed similarity in the NMR spectra with the signals of cyclomicrophylline A (5). For instance, the ${ }^{1} \mathrm{H} /{ }^{13} \mathrm{C}-\mathrm{HSQC}$ spectrum displayed the typical interactions of the proton in the hydroxylated position 16 at $\delta_{\mathrm{H}}=4.31$ with $\delta \mathrm{c}=77.20$ and the signals of the hydroxylated methylene group in position 29 at $\delta_{\mathrm{H}}=3.86$ and $3.32(\mathrm{~d}, 11.2 \mathrm{~Hz})$ with $\delta c=64.35$. Alternatively, the resonances of the olefinic methine protons are missing, which suggested a saturated B-ring. In the ${ }^{13} \mathrm{C}-\mathrm{NMR}$ spectrum, a signal at $\delta \mathrm{c}=217.33$ could be detected in the low field in the typical shift range of a ketone [29]. The ${ }^{2} \mathrm{~J}$ and ${ }^{3} \mathrm{~J}$ couplings in the ${ }^{1} \mathrm{H} /{ }^{13} \mathrm{C}-\mathrm{HMBC}$ spectrum of the ketone carbon with positions 1,2, 29 and 30 clearly assigned it to $\mathrm{C}-3$. This position also appears plausible from a biosynthetic point of view [28] for the elucidated new structure (Figure 2).

In the +ESI-QqTOF MS/MS spectrum (Figure S121, Supplementary Materials), compound 23 exhibited identical fragmentation (the fragmentation pathway is reported for the first time in Figure S122, Supplementary Materials) with N-benzoyl-O-acetylbuxodienine-E (22). The molecular formula $\mathrm{C}_{35} \mathrm{H}_{50} \mathrm{~N}_{2} \mathrm{O}_{3}$, derived from the quasimolecular ions $(\mathrm{m} / \mathrm{z}$ $274.1989[\mathrm{M}+2 \mathrm{H}]^{2+}, 547.3917[\mathrm{M}+\mathrm{H}]^{+}$) and the resulting 12 double bond equivalents of the two substances, agree. Thus, the present compound's structure must be very similar to that of the already known congener and represents an isomer of 22. The UV spectrum (Figure S123, Supplementary Materials) of structure 23 indicated the presence of a secondary benzamide with an absorption maximum at $225 \mathrm{~nm}$ [10]. The absorption of a diene system, as in compound 22 ( $\lambda_{\max }$ at 237, 245 and $253 \mathrm{~nm}$, Figure S114, Supplementary Materials), was not detectable. The signals of the NMR spectra (Table 3; Figures S124-S133, Supplementary Materials) of $\mathbf{2 2}$ and $\mathbf{2 3}$ were very similar for the most part. Deviations occurred in the chemical shifts at positions $\mathrm{C}-11$ and $\mathrm{C}-19$ in the A-ring. In the ${ }^{1} \mathrm{H} /{ }^{13} \mathrm{C}-\mathrm{HSQC}$ spectrum of compound 23, two signals could be detected at $\delta_{\mathrm{H}}=5.42(\mathrm{br} \mathrm{s}) / \delta \mathrm{c}=121.95$, as well as $\delta_{\mathrm{H}}=5.31(\mathrm{br} \mathrm{m}) / \delta \mathrm{c}=119.37$, which indicated olefinic structural elements. In the ${ }^{1} \mathrm{H} /{ }^{13} \mathrm{C}-\mathrm{HMBC}$ spectrum, these signals did not show any interaction with each other, as would be expected in a conjugated $\Delta^{9(11), 10(19)}$ system as found in 22. Instead, the chemical shifts agree with a $(9-(10 \rightarrow 19))$ abeo-pregnane with the presence of two isolated double bonds, i.e., $\Delta^{1(10)}$ and $\Delta^{9(11)}[28,30]$. Consequently, compound 23 could be identified as a constitutional isomer of 22 with a double bond between C-1 and C-10, instead of C-10 and C-19 (Figure 2). 
Table 3. ${ }^{1} \mathrm{H}$ - and ${ }^{13} \mathrm{C}-\mathrm{NMR}$ data of compounds 11, $23\left(600 / 150 \mathrm{MHz}, \mathrm{CD}_{3} \mathrm{OD}\right), 24$ and 25 (600/150 MHz, $\left.\mathrm{CDCl}_{3}\right)$.

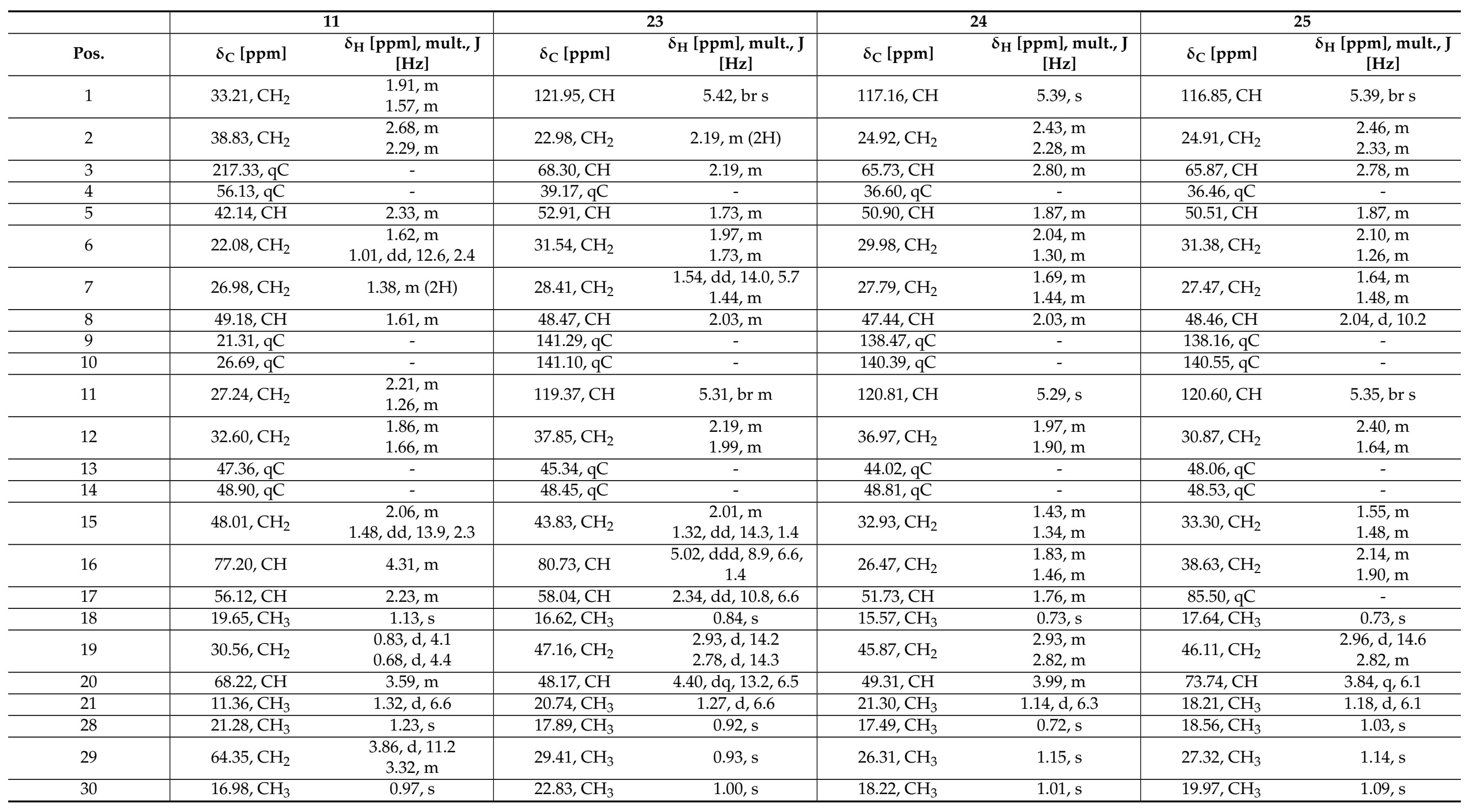


Table 3. Cont.

\begin{tabular}{|c|c|c|c|c|c|c|c|c|}
\hline \multirow[b]{2}{*}{ Pos. } & \multicolumn{2}{|c|}{11} & \multicolumn{2}{|c|}{23} & \multicolumn{2}{|c|}{24} & \multicolumn{2}{|c|}{25} \\
\hline & $\delta_{C}[p p m]$ & $\begin{array}{c}\delta_{H}[p p m], \text { mult., } J \\
{[\mathrm{~Hz}]}\end{array}$ & $\delta_{C}[p p m]$ & $\begin{array}{c}\delta_{\mathrm{H}}[\mathrm{ppm}], \text { mult., } \mathrm{J} \\
{[\mathrm{Hz}]}\end{array}$ & $\delta_{C}[p p m]$ & $\begin{array}{c}\delta_{\mathbf{H}}[\mathrm{ppm}], \text { mult., } \mathbf{J} \\
{[\mathrm{Hz}]}\end{array}$ & $\delta_{C}[p p m]$ & $\begin{array}{c}\delta_{H}[p p m], \text { mult., } J \\
{[\mathrm{~Hz}]}\end{array}$ \\
\hline $31 / 32$ & & & $45.32, \mathrm{CH}_{3}$ & $2.30, \mathrm{~s}(6 \mathrm{H})$ & $33.38, \mathrm{CH}_{3}$ & $2.72, \mathrm{~s}(3 \mathrm{H})$ & $34.09, \mathrm{CH}_{3}$ & $2.75, \mathrm{~s}(3 \mathrm{H})$ \\
\hline \multirow[t]{2}{*}{$33 / 34$} & $43.67, \mathrm{CH}_{3}$ & $2.96, \mathrm{~s}(3 \mathrm{H})$ & & & & & & \\
\hline & $36.65, \mathrm{CH}_{3}$ & $2.81, \mathrm{~s}(3 \mathrm{H})$ & & & & & & \\
\hline $\mathrm{Ac}-\mathrm{CH}_{3}$ & & & $20.97, \mathrm{CH}_{3}$ & $1.62, \mathrm{~s}$ & $23.35, \mathrm{CH}_{3}$ & $1.99, \mathrm{~s}$ & & \\
\hline $\mathrm{Ac}-\mathrm{CO}$ & & & $172.40, \mathrm{qC}$ & - & $170.18, \mathrm{qC}$ & - & & \\
\hline OCNH & & & $168.61, \mathrm{qC}$ & - & - & $5.46, \mathrm{~d}(1 \mathrm{H}), 9.0$ & & \\
\hline $2^{\prime}$ & & & $128.28, \mathrm{CH}$ & $7.78, \mathrm{~m}$ & & & & \\
\hline $3^{\prime}$ & & & $129.45, \mathrm{CH}$ & $7.44, \mathrm{~m}$ & & & & \\
\hline $4^{\prime}$ & & & $132.54, \mathrm{CH}$ & $7.51, \mathrm{~m}$ & & & & \\
\hline $5^{\prime}$ & & & $129.45, \mathrm{CH}$ & $7.44, \mathrm{~m}$ & & & & \\
\hline $6^{\prime}$ & & & $128.28, \mathrm{CH}$ & $7.78, \mathrm{~m}$ & & & & \\
\hline
\end{tabular}


For compound 24, the molecular formula was determined as $\mathrm{C}_{27} \mathrm{H}_{44} \mathrm{~N}_{2} \mathrm{O}$ by LC/MS. The +ESI-QqTOF mass spectrum (Figure S135, Supplementary Materials) showed protonated ion signals at $m / z 207.4721[\mathrm{M}+2 \mathrm{H}]^{2+}$ and $m / z 413.0273[\mathrm{M}+\mathrm{H}]^{+}$, in which the intensity of the $[\mathrm{M}+\mathrm{H}]^{+}$clearly outweighed the signal of the $[\mathrm{M}+2 \mathrm{H}]^{2+}$ (as in the +ESI-QqTOF mass spectrum of compound 9, 10 and 21-23). This implied a structure with two nitrogen groups, which have clearly different basicities. The fragmentation in the +ESI-QqTOF MS/MS spectrum (Figure S136, Supplementary Materials) with a neutral loss of 31 Da suggested the presence of a monomethylamino group at C-3 or C-20 $(\mathrm{m} / \mathrm{z}=$ $\left.382\left[\mathrm{M}-\mathrm{CH}_{3} \mathrm{NH}_{2}\right]^{+}\right)$. The fragment at $\mathrm{m} / z=323\left[382-\mathrm{CH}_{3} \mathrm{CONH}_{2}\right]^{+}$indicated the neutral loss of an acetamide group (-59 Da). By means of the NMR spectroscopic data (Table 3; Figures S137-S145, Supplementary Materials), compound 24, in analogy with 23, could clearly be assigned to the Buxus-alkaloids with a $(9-(10 \rightarrow 19))$ abeo-pregnane backbone and isolated double bonds between C-1 and 10 and between C-9 and 11. The acetamide group, already suspected by the fragmentation, could be located at the nitrogen atom at $\mathrm{C}-20$ by the cross signal of the carbonyl carbon $\left(\delta_{\mathrm{C}}=170.18\right)$ with the proton at position $20\left(\delta_{\mathrm{H}}=\right.$ $3.99)$ in the ${ }^{1} \mathrm{H} /{ }^{13} \mathrm{C}-\mathrm{HMBC}$ spectrum. This amide group has a significantly reduced basicity in contrast to the secondary amine group in position 3, which provides an explanation for the low intensity of the $[\mathrm{M}+2 \mathrm{H}]^{2+}$ quasimolecular ion in the +ESI-QqTOF mass spectrum. The resulting structure is presented in Figure 2.

The LC/MS analysis (Figures S146-S148, Supplementary Materials) of compound 25 indicated the molecular formula $\mathrm{C}_{25} \mathrm{H}_{41} \mathrm{NO}_{2}$. The fragmentation (Figure S148, Supplementary Materials) already gave rise to some structural features that are contained in compound 25. The fragment at $m / z 339\left[\mathrm{M}-\left(\mathrm{CH}_{3} \mathrm{NH}_{2}\right)-\left(\mathrm{H}_{2} \mathrm{O}\right)\right]^{+}$resulted from the loss of a monomethylated amino group, together with the elimination of a hydroxyl group as a water molecule. The following fragment at $m / z 321\left[339-\mathrm{H}_{2} \mathrm{O}\right]^{+}$showed an additional hydroxyl group. By evaluating the NMR spectra (Table 3; Figures S149-S158, Supplementary Materials), compound 25 was clearly identified as a Buxus-alkaloid with a $(9-(10 \rightarrow 9))$ abeopregnane skeleton and isolated double bonds between $\mathrm{C}-1$ and $\mathrm{C}-10$ and between $\mathrm{C}-9$ and C-11. A methine proton signal at $\delta_{\mathrm{H}}=3.84\left(\delta_{\mathrm{C}}=73.7\right.$ according to the ${ }^{1} \mathrm{H} /{ }^{13} \mathrm{C}-\mathrm{HSQC}$ spectrum) resonated as a quartet $(\mathrm{J}=6.1 \mathrm{~Hz})$ and should therefore be in geminal position with a methyl group and must represent position 20. In the ${ }^{1} \mathrm{H} /{ }^{13} \mathrm{C}-\mathrm{HMBC}$ spectrum, this proton showed cross peaks with carbons at $\delta_{\mathrm{C}}=18.21\left(\mathrm{CH}_{3}\right), 38.63\left(\mathrm{CH}_{2}\right)$, and 85.50 (quaternary $\mathrm{C}$ ). The signal at $\delta_{\mathrm{C}}=18.21$ was assigned the methyl group in position $21\left(\delta_{\mathrm{H}}=\right.$ $1.18(\mathrm{~d}, \mathrm{~J}=6.1))$, whereas $\delta_{\mathrm{C}}=38.63$ could be assigned to the methylene group in position 16. The quaternary carbon at $\delta_{C}=85.50$ resonated in the typical shift range of a tertiary alcohol group and could be assigned to position 17 . The present alkaloid thus possesses a vicinal diol structure at positions 17 and 20 (Figure 2).

The generic names of the new natural products were chosen based on the existing classification for Buxus-alkaloids [31,32]: O-tigloylcyclomicrophylline-B (3), O-tigloylcyclo microphylline-A (4), cyclomicrophyllidine-B (7), O-benzoyl-cycloprotobuxoline-D (8), 29hydroxy-cyclomikuranine-L (11), N-benzoyl-O-acetylbuxadine-E (23), $\mathrm{N}_{20}$-acetylbuxadine$\mathrm{G}$ (24), and 17,20-dihydroxybuxadine-M (25). Compound 24 was concurrently isolated by Xiang et al. [33]. We prefer the systematic generic name $\mathrm{N}_{20}$-acetylbuxadine- $\mathrm{G}$ for this substance. The chemical structures of the new natural products are reported in Figure 2.

\subsection{In Vitro Antiprotozoal Activity of Isolated Compounds}

After isolation, all alkaloids were tested in vitro for antiplasmodial and antitrypanosomal activity against Plasmodium falciparum (Pf) and Trypanosoma brucei rhodesiense (Tbr). Furthermore, to assess their selectivity against the parasites, cytotoxicity against L6 rat skeletal myoblasts, as mammalian control cells, was tested (Table 4). 
Table 4. In vitro antiprotozoal and cytotoxic activity of isolated Buxus-alkaloids.

\begin{tabular}{|c|c|c|c|c|c|}
\hline Cpd & $P f$ & $T b r$ & Cytotox. & SI Pf & SI Tbr \\
\hline 1 & $\begin{array}{c}0.52 \pm 0.14 \\
(1.05 \mu \mathrm{M})\end{array}$ & $\begin{array}{c}1.6 \pm 0.55^{*} \\
(3.2 \mu \mathrm{M})\end{array}$ & $\begin{array}{c}9.4 \pm 3.8 \\
(19 \mu \mathrm{M})\end{array}$ & 18 & 6 \\
\hline 2 & $\begin{array}{c}1.07 \pm 0.11 \\
(2.6 \mu \mathrm{M})\end{array}$ & $\begin{array}{c}0.6 \pm 0.03 \\
(1.5 \mu \mathrm{M})\end{array}$ & $\begin{array}{l}14.7 \pm 3.1 \\
(35.5 \mu \mathrm{M})\end{array}$ & 14 & 25 \\
\hline 3 & $\begin{array}{l}0.5 \pm 0.06 \\
(0.98 \mu \mathrm{M})\end{array}$ & $\begin{array}{l}4.6 \pm 0.005 \\
(9 \mu \mathrm{M})\end{array}$ & $\begin{array}{c}35.8 \pm 13.6 \\
(69.9 \mu \mathrm{M})\end{array}$ & 72 & 8 \\
\hline 4 & $\begin{array}{c}0.35 \pm 0.08 \\
(0.7 \mu \mathrm{M})\end{array}$ & $\begin{array}{c}1.5 \pm 0.76^{*} \\
(2.9 \mu \mathrm{M})\end{array}$ & $\begin{array}{c}12 \pm 1.4 \\
(22.8 \mu \mathrm{M})\end{array}$ & 34 & 8 \\
\hline 5 & $\begin{array}{c}0.78 \pm 0.08 \\
(1.76 \mu \mathrm{M})\end{array}$ & $\begin{array}{c}1.04 \pm 0.27 \text { * } \\
(2.34 \mu \mathrm{M})\end{array}$ & $\begin{array}{l}44 \pm 2.3 \\
(99 \mu \mathrm{M})\end{array}$ & 56 & 42 \\
\hline 6 & $\begin{array}{c}0.4 \pm 0.02 \\
(0.7 \mu \mathrm{M})\end{array}$ & $\begin{array}{c}0.69 \pm 0.06 \\
(1.3 \mu \mathrm{M})\end{array}$ & $\begin{array}{c}9.3 \pm 3 \\
(17 \mu \mathrm{M})\end{array}$ & 23 & 14 \\
\hline 7 & $\begin{array}{c}0.11 \pm 0.01 \\
(0.2 \mu \mathrm{M})\end{array}$ & $\begin{array}{l}1.9 \pm 0.3 \\
(3.6 \mu \mathrm{M})\end{array}$ & $\begin{array}{c}16 \pm 0.2 \\
(29.9 \mu \mathrm{M})\end{array}$ & 145 & 8 \\
\hline 8 & $\begin{array}{c}0.09 \pm 0.03^{*} \\
(0.18 \mu \mathrm{M})\end{array}$ & $\begin{array}{c}0.55 \pm 0.18 \\
(1.1 \mu \mathrm{M})\end{array}$ & $\begin{array}{c}6.65 \pm 0.38 \\
(13.1 \mu \mathrm{M})\end{array}$ & 74 & 12 \\
\hline 9 & $\begin{array}{c}2.15 \pm 0.29 \\
(3.8 \mu \mathrm{M})\end{array}$ & $\begin{array}{c}1.35 \pm 0.45^{*} \\
(2.4 \mu \mathrm{M})\end{array}$ & $\begin{array}{l}41 \pm 0.7 \\
(73 \mu \mathrm{M})\end{array}$ & 19 & 30 \\
\hline 11 & $\begin{array}{c}0.9 \pm 0.13 \\
(2.2 \mu \mathrm{M})\end{array}$ & $\begin{array}{l}2.9 \pm 1 \\
(7 \mu \mathrm{M})\end{array}$ & $\begin{array}{c}44 \pm 1.3 \\
(105.4 \mu \mathrm{M})\end{array}$ & 49 & 15 \\
\hline 12 & $\begin{array}{c}1.4 \pm 0.44^{*} \\
(3.5 \mu \mathrm{M})\end{array}$ & $\begin{array}{l}2.5 \pm 0.1 \\
(6.3 \mu \mathrm{M})\end{array}$ & $\begin{array}{c}19 \pm 1.2 \\
(47.6 \mu \mathrm{M})\end{array}$ & 14 & 8 \\
\hline $13+14$ & $\begin{array}{c}1.6 \pm 0.18 \text { * } \\
(4.3 \mu \mathrm{M})\end{array}$ & $\begin{array}{c}0.8 \pm 0.06 \\
(2.2 \mu \mathrm{M})\end{array}$ & $\begin{array}{l}5.3 \pm 0.05 \\
(14.4 \mu \mathrm{M})\end{array}$ & 3 & 7 \\
\hline $15+16$ & $\begin{array}{c}1.1 \pm 0.01 \\
(3.1 \mu \mathrm{M})\end{array}$ & $\begin{array}{c}0.75 \pm 0.001 \\
(2.1 \mu \mathrm{M})\end{array}$ & $\begin{array}{c}10.4 \pm 4.17 \\
(29.4 \mu \mathrm{M})\end{array}$ & 9 & 14 \\
\hline 17 & $\begin{array}{c}4.1 \pm 0.8 \\
(10.9 \mu \mathrm{M})\end{array}$ & $\begin{array}{c}48 \pm 0.2 \\
(129.3 \mu \mathrm{M})\end{array}$ & $\begin{array}{c}30.5 \pm 9.6 \\
(82 \mu \mathrm{M})\end{array}$ & 7 & 0.6 \\
\hline 18 & $\begin{array}{c}2.6 \pm 0.005 \\
(6.8 \mu \mathrm{M})\end{array}$ & $\begin{array}{c}16.9 \pm 2.3 \\
(44 \mu \mathrm{M})\end{array}$ & $\begin{array}{l}26.8 \pm 8.8 \\
(69.6 \mu \mathrm{M})\end{array}$ & 10 & 2 \\
\hline 19 & $\begin{array}{c}1.3 \pm 0.35^{*} \\
(3.8 \mu \mathrm{M})\end{array}$ & $\begin{array}{c}2.2 \pm 0.07 \\
(6.4 \mu \mathrm{M})\end{array}$ & $\begin{array}{l}13.4 \pm 0.5 \\
(38.8 \mu \mathrm{M})\end{array}$ & 10 & 6 \\
\hline 20 & $\begin{array}{c}1.6 \pm 0.57 \text { * } \\
(4 \mu \mathrm{M})\end{array}$ & $\begin{array}{l}5.26 \pm 0.3 \\
(13.2 \mu \mathrm{M})\end{array}$ & $\begin{array}{c}45 \pm 1 \\
(112.7 \mu \mathrm{M})\end{array}$ & 28 & 9 \\
\hline 21 & $\begin{array}{c}3.1 \pm 0.24 \\
(7.3 \mu \mathrm{M})\end{array}$ & $\begin{array}{c}53 \pm 1 \\
(124 \mu \mathrm{M})\end{array}$ & $\begin{array}{c}54.8 \pm 1.1 \\
(129 \mu \mathrm{M})\end{array}$ & 18 & 1 \\
\hline 22 & $\begin{array}{c}3 \pm 0.3 \\
(6.2 \mu \mathrm{M})\end{array}$ & $\begin{array}{c}3.4 \pm 1 \\
(6.2 \mu \mathrm{M})\end{array}$ & $\begin{array}{c}8.5 \pm 0.1 \\
(15.6 \mu \mathrm{M})\end{array}$ & 3 & 3 \\
\hline 23 & $\begin{array}{l}4.2 \pm 0.4 \\
(7.7 \mu \mathrm{M})\end{array}$ & $\begin{array}{l}3.1 \pm 0.6 \\
(5.7 \mu \mathrm{M})\end{array}$ & $\begin{array}{l}27.5 \pm 16 \\
(50.4 \mu \mathrm{M})\end{array}$ & 7 & 9 \\
\hline 24 & $\begin{array}{c}2.3 \pm 0.27 \\
(5.6 \mu \mathrm{M})\end{array}$ & $\begin{array}{c}0.52 \pm 0.27 \text { * } \\
(1.3 \mu \mathrm{M})\end{array}$ & $\begin{array}{c}16.9 \pm 1.1 \\
(41 \mu \mathrm{M})\end{array}$ & 7 & 33 \\
\hline 25 & $\begin{array}{c}3.6 \pm 0.05 \\
(9.3 \mu \mathrm{M})\end{array}$ & $\begin{array}{l}6.7 \pm 0.49 \\
(17.3 \mu \mathrm{M})\end{array}$ & $\begin{array}{c}44.5 \pm 5.5 \\
(114.9 \mu \mathrm{M})\end{array}$ & 12 & 7 \\
\hline Chloroquine & $\begin{array}{c}0.006 \pm 0.001 \\
(0.019 \mu \mathrm{M})\end{array}$ & & & & \\
\hline Melarsoprol & & $\begin{array}{c}0.005 \pm 0.001 \\
(0.013 \mu \mathrm{M})\end{array}$ & & & \\
\hline Podophyllotoxin & & & $\begin{array}{c}0.006 \pm 0.001 \\
(0.014 \mu \mathrm{M})\end{array}$ & & \\
\hline
\end{tabular}

$\mathrm{All}_{\mathrm{IC}}$ values are expressed in $\mu \mathrm{g} / \mathrm{mL}$ and values in $\mu \mathrm{M}$ are given in parentheses. While ${ }^{*} n=3$ was reported as the mean value from three independent measurements with the standard deviation, all other values were determined with $n=2$ as the mean value from two independent measurements with the fluctuation range. Note that the purity of compound $\mathbf{1 0}$ was $<90 \%$, so that activity was not determined.

Compounds 3, 4 and 6-8 showed conspicuous activity against $P f$ with $\mathrm{IC}_{50}$ values $<1.0 \mu \mathrm{M}$. The new natural products, O-benzoyl-cycloprotobuxoline-D (8) and cyclomicrop hyllidine-B (7), were the most active antiplasmodial compounds with $\mathrm{IC}_{50}$ values of 0.18 and $0.2 \mu \mathrm{M}$ and SI values of 74 and 145, respectively. Except for compounds 17 (IC 50 
$10.9 \mu \mathrm{M})$ and $18\left(\mathrm{IC}_{50} 6.8 \mu \mathrm{M}\right)$, all other $9 \beta$-19-cyclo- $5 \alpha$-pregnanes $(\mathbf{1}, \mathbf{2}, \mathbf{5}, \mathbf{9}, \mathbf{1 1}-\mathbf{1 6})$ and the steroidal alkaloid (19) displayed moderate activities with $\mathrm{IC}_{50}$ values in the range of 1.05 to $4.3 \mu \mathrm{M}$. The $(9-(10 \rightarrow 19))$ abeo-5 $\alpha$-pregnanes $(20-25)$ were less active with $\mathrm{IC}_{50}$ values of $>4.0 \mu \mathrm{M}$.

Promising antitrypanosomal activities with $\mathrm{IC}_{50}$ values between 1.1 and $1.5 \mu \mathrm{M}$ were recorded for compounds $\mathbf{2 , 6}, \mathbf{8}$ and $\mathbf{2 4}$. In common with the tests against Pf, O-benzoylcycloprotobuxoline-D (8) ( $\mathrm{IC}_{50} 1.1 \mu \mathrm{M}$; SI 12) was the most effective antitrypanosomal Buxus-alkaloid in this set of compounds. Cyclomicrophylline-A (5) showed the highest selectivity against $\mathrm{Tbr}$ (SI 42). Compounds 1, 4, 5, 7, 9 and 13-16 were moderately active, with $\mathrm{IC}_{50}$ values varying between 2.1 and $3.6 \mu \mathrm{M}$. The $\mathrm{IC}_{50}$ values of the other alkaloids against $\mathrm{Tbr}$ were $>5.7 \mu \mathrm{M}$, indicating a low level of activity.

\section{Materials and Methods}

\subsection{Plant Material}

The same plant material was used as described previously [11].

\subsection{Extraction and Isolation of Alkaloids from the B. sempervirens Leaf Extract}

The extraction of plant material, the first part of the isolation procedure, and the isolation of O-tigloylcyclovirobuxeine-B (1) was equal to our previous study (Scheme 1) [11].

After the second CPC separation of Fraction 2 (F2) [11], test tubes $44-47$ (7 mg) contained compound 4 as a main constituent. A Sephadex-LH 20 column $(15 \times 40 \mathrm{~cm}$, flow $0.4 \mathrm{~mL} / \mathrm{min}$ ) was applied for purification of 4 using $\mathrm{MeOH}$ (isocratic, $100 \mathrm{~mL}$ ) as eluent. Compound 4 (2.2 mg) was obtained as a white powder. The CPC test tubes 55-60 consisted of pure compound $6(11.8 \mathrm{mg})$. CPC fractions $5+6(103.2 \mathrm{mg}), 8(138.0 \mathrm{mg})$, and 16 (108.4 mg) were separated on an RP18 phase (Macherey-Nagel, Nucleodur C-18 HTec, $250 \times 21 \mathrm{~mm}, 5 \mu \mathrm{m})$ using a $\mathrm{H}_{2} \mathrm{O}(+0.1 \%$ TFA; $): \mathrm{ACN}(+0.1 \%$ TFA; B) gradient $(0 \mathrm{~min}:$ 5\% B; 5 min: 20\% B; 12.5 min: 30\% B; 14 min: 32\% B; 22 min: 35\% B; 35 min: 100\% B; and $40 \mathrm{~min}: 100 \% \mathrm{~B})$ by prep-HPLC. Fractions 5 and 6 resulted in the isolation of compound 8 $\left(1.6 \mathrm{mg}, \mathrm{t}_{\mathrm{R}} 20.0 \mathrm{~min}\right), \mathbf{1 2}\left(2.8 \mathrm{mg}, \mathrm{t}_{\mathrm{R}} 27.6 \mathrm{~min}\right), \mathbf{1 3}+\mathbf{1 4}\left(5.4 \mathrm{mg}, \mathrm{t}_{\mathrm{R}} 29.2 \mathrm{~min}\right), \mathbf{1 9}\left(6.5 \mathrm{mg}, \mathrm{t}_{\mathrm{R}}\right.$ $20.8 \mathrm{~min}), 20\left(5.6 \mathrm{mg}, \mathrm{t}_{\mathrm{R}} 19.2 \mathrm{~min}\right), 21\left(3.7^{\prime} \mathrm{mg}, \mathrm{t}_{\mathrm{R}} 27.2 \mathrm{~min}\right)$, and $22\left(4.3 \mathrm{mg}, \mathrm{t}_{\mathrm{R}} 29.6 \mathrm{~min}\right)$. The separation of fraction 8 yielded substance $3\left(6.7 \mathrm{mg}, \mathrm{t}_{\mathrm{R}} 16.4 \mathrm{~min}\right), 7\left(4.0 \mathrm{mg}, \mathrm{t}_{\mathrm{R}} 17.2 \mathrm{~min}\right), 15$ + $16\left(19.6 \mathrm{mg}, \mathrm{t}_{\mathrm{R}} 28.0 \mathrm{~min}\right)$, and $25\left(14.5 \mathrm{mg}, \mathrm{t}_{\mathrm{R}} 24.4 \mathrm{~min}\right)$. Compound $9\left(1.9 \mathrm{mg}, \mathrm{t}_{\mathrm{R}} 26.2 \mathrm{~min}\right)$, $10\left(2.0 \mathrm{mg}, \mathrm{t}_{\mathrm{R}} 27.0 \mathrm{~min}\right), \mathbf{1 1}\left(3.8 \mathrm{mg}, \mathrm{t}_{\mathrm{R}} 19.0 \mathrm{~min}\right)$, and $24\left(7.3 \mathrm{mg}, \mathrm{t}_{\mathrm{R}} 28.2 \mathrm{~min}\right)$ were obtained by prep-HPLC of fraction 16.

CPC fractions F14 and F18+F19 presented 18 (28.6 mg) and 17 (391.5 mg) as pure compounds, respectively. Compound $23(10.0 \mathrm{mg})$ was obtained from the crude dichloromethane extract by CC on silica gel (Merck, type-60, 70-230 mesh). The separation was introduced by gradient elution of ethyl acetate (EtOAc) (100\%) until eluates became clear (eluates contained no alkaloid), followed by EtOAc saturated with aq. ammonia ( $3.5 \mathrm{~L}$, flow $1 \mathrm{~mL} / \mathrm{min}$ ). Six fractions (five alkaloidal) were collected in $20 \mathrm{~mL}$ tubes (Bs1, Bs2a, Bs3a, Bs4a, Bs5a (starting from tube 78) and Bs6a). Bs2a was further purified using isocratic aq. ammoniasaturated EtOAc in a smaller silica gel column (flow $0.4 \mathrm{~mL} / \mathrm{min}$ ) and yielded $10.0 \mathrm{mg}$ of compound 23 (white powder).

\subsection{Alkaline Hydrolysis of the Esters 1 and $\mathbf{6}$}

The corresponding free alcohols 2 and 5 were obtained from the already isolated compounds 1 and $\mathbf{6}$ by non-aqueous alkaline ester hydrolysis [34,35]. The esters $\mathbf{1}(32.0 \mathrm{mg})$ and $6(4.7 \mathrm{mg})$ were hydrolyzed with $0.5 \mathrm{~N} \mathrm{NaOH}$ in a dichloromethane-methanol mixture $(9: 1 \mathrm{v} / \mathrm{v})$ at room temperature. The completion of the reaction (1 to 2: $4 \frac{1}{2} \mathrm{~h}$ and 6 to 5: $6 \mathrm{~d}$, $14 \frac{1}{2} \mathrm{~h}$ ) was monitored by thin layer chromatography (TLC plate silica gel $60 \mathrm{~F}_{254}$, Merck KGaA, Darmstadt, Germany; mobile phase: butan-1-ol: $\mathrm{H}_{2} \mathrm{O}: \mathrm{CH}_{3} \mathrm{COOH}(10: 3: 1)(v / v / v)$, detected with Liebermann-Burchard reagent (acetic anhydride $(5 \mathrm{~mL})$, sulfuric acid $(5 \mathrm{~mL})$, and ethanol (50 mL), European Pharmacopoeia Reagent)), and the resulting alcohols were purified by extraction (four times with $100 \mathrm{~mL}$ dichloromethane). The yield in each case 
was $>85 \%: 2(22.8 \mathrm{mg})$ and $5(3.2 \mathrm{mg})$. Since these two compounds are only found in small amounts in the crude extract of $B$. sempervirens L., ester hydrolysis was used to increase the yield.

\subsection{Spectroscopic Analysis of Isolated Compounds}

NMR spectra were recorded on an Agilent DD2 $600 \mathrm{MHz}$ spectrometer (Agilent, Santa Clara, CA, USA) at $25^{\circ} \mathrm{C}$ in $\mathrm{CDCl}_{3}$ or $\mathrm{CD}_{3} \mathrm{OD}$. Spectra were referenced to the solvent signals $\left(\mathrm{CDCl}_{3}\right.$ : ${ }^{1} \mathrm{H}$ : 7.260 ppm; ${ }^{13} \mathrm{C}: 77.160$ ppm; $\mathrm{CD}_{3} \mathrm{OD}:{ }^{1} \mathrm{H}: 3.310 \mathrm{ppm}$; and $\left.{ }^{13} \mathrm{C}: 49.000 \mathrm{ppm}\right)$ and were evaluated with MestReNova version 11.0 software (Mestrelab Research, Santiago de Compostela, Spain).

UHPLC/+ESI-QqTOF-MS/MS measurements were performed as described previously [11]. The sample concentration of the crude extract was $10 \mathrm{mg} / \mathrm{mL}$ in case of the CPC fractions $1 \mathrm{mg} / \mathrm{mL}$, and for the isolated compounds it was $0.1 \mathrm{mg} / \mathrm{mL}$.

UV spectra of compounds 22 and 23 were recorded with a U-2900 spectrophotometer (Hitachi, Tokyo, Japan) in methanol.

\subsection{Spectral Data of Isolated Buxus-Alkaloids}

O-tigloylcyclovirobuxeine-B (1): previously described in [6,11].

Cyclovirobuxeine-B (2): white powder; ${ }^{1} \mathrm{H}$ NMR $\left(600 \mathrm{MHz}, \mathrm{CDCl}_{3} ; \delta\right.$ (ppm), intensity, mult., J (Hz)): 5.62 (1H, ddd, 10.6, 1.4, 1.4, H-6), 5.40 (1H, ddd, 10.6, 6.0, 3.1, H-7), 4.17 (1H, ddd, 9.2, 6.7, 2.1, H-16), 2.57 (1H, m, H-20), 2.53 (1H, dd, 5.8, 2.2, H-8), 2.47 (3H, s, H-33/34), 2.29 (6H, s, H-31/32), $2.06(1 \mathrm{H}, \mathrm{m}, \mathrm{H}-3), 1.98(1 \mathrm{H}, \mathrm{dd}, 13.2,9.7, \mathrm{H}-15 \alpha), 1.86(1 \mathrm{H}$, m, H-5), $1.82(1 \mathrm{H}, \mathrm{dd}, 14.6,5.7, \mathrm{H}-11 \alpha), 1.75(1 \mathrm{H}, \mathrm{m}, \mathrm{H}-2 \alpha), 1.69$ (1H, td, 13.3, 5.0, H-12 $\alpha)$, $1.63(1 \mathrm{H}, \mathrm{dd}, 10.5,6.7, \mathrm{H}-17), 1.54(1 \mathrm{H}, \mathrm{m}, \mathrm{H}-2 \beta), 1.53$ (2H, m, H-1), 1.41 (1H, ddd, 15.0, 5.1, 1.9, H-11ß), $1.36(1 \mathrm{H}, \mathrm{m}, \mathrm{H}-12 \beta), 1.28(1 \mathrm{H}, \mathrm{m}, \mathrm{H}-15 \beta), 1.12(3 \mathrm{H}, \mathrm{d}, 6.2, \mathrm{H}-21), 1.06(3 \mathrm{H}, \mathrm{s}$, H-29), 0.94 (3H, s, H-28), 0.91 (3H, s, H-18), 0.79 (3H, s, H-30), 0.72 (1H, d, 4.0, H-19 $),-0.21$ $(1 \mathrm{H}, \mathrm{d}, 4.0, \mathrm{H}-19 \beta)$;

${ }^{13} \mathrm{C} \mathrm{NMR}\left(150 \mathrm{MHz}, \mathrm{CDCl}_{3} ; \delta(\mathrm{ppm})\right): 128.37(\mathrm{CH}, \mathrm{C}-7), 127.72(\mathrm{CH}, \mathrm{C}-6), 78.70(\mathrm{CH}$, C-16), 71.43 (CH, C-3), 61.15 (CH, C-17), 59.17 (CH, C-20), 49.86 (qC, C-14), 48.78 (CH, C-5), 45.62 (qC, C-13), $44.31\left(\mathrm{CH}_{3}, \mathrm{C}-31 / 32\right), 43.37(\mathrm{CH}, \mathrm{C}-8), 41.94\left(\mathrm{CH}_{2}, \mathrm{C}-15\right), 41.60$ (qC, C-4), $33.52\left(\mathrm{CH}_{3}, \mathrm{C}-33 / 34\right), 32.10\left(\mathrm{CH}_{2}, \mathrm{C}-12\right), 31.15\left(\mathrm{CH}_{2}, \mathrm{C}-1\right), 28.86(\mathrm{qC}, \mathrm{C}-10), 26.17\left(\mathrm{CH}_{3}\right.$, C-29), $24.96\left(\mathrm{CH}_{2}, \mathrm{C}-11\right), 20.92$ (qC, C-9), $20.03\left(\mathrm{CH}_{2}, \mathrm{C}-2\right), 18.77\left(\mathrm{CH}_{2}, \mathrm{C}-19\right), 18.63\left(\mathrm{CH}_{3}\right.$, $\mathrm{C}-21), 18.39\left(\mathrm{CH}_{3}, \mathrm{C}-28\right), 16.66\left(\mathrm{CH}_{3}, \mathrm{C}-30\right), 15.70\left(\mathrm{CH}_{3}, \mathrm{C}-18\right)$.

+ ESI-QqTOF-MS $(m / z): 415.3696[\mathrm{M}+\mathrm{H}]^{+}, 208.1902[\mathrm{M}+2 \mathrm{H}]^{2+}\left(\right.$ calcd for $\mathrm{C}_{27} \mathrm{H}_{47} \mathrm{~N}_{2} \mathrm{O}^{+}$: 415.3688, for $\left.\mathrm{C}_{27} \mathrm{H}_{48} \mathrm{~N}_{2} \mathrm{O}^{2+}: 208.1884\right)$.

O-tigloylcyclomicrophylline-B (3): colorless gum; ${ }^{1} \mathrm{H}$ NMR and ${ }^{13} \mathrm{C}$ NMR $(600 / 150 \mathrm{MHz}$, $\mathrm{CDCl}_{3}$ ) see Table 2;

+ESI-QqTOF-MS $(m / z): 513.4221[\mathrm{M}+\mathrm{H}]^{+}, 257.2174[\mathrm{M}+2 \mathrm{H}]^{2+}\left(\operatorname{calcd}\right.$ for $\mathrm{C}_{32} \mathrm{H}_{53} \mathrm{~N}_{2} \mathrm{O}_{3}{ }^{+}$: 513.4056, for $\mathrm{C}_{32} \mathrm{H}_{54} \mathrm{~N}_{2} \mathrm{O}_{3}{ }^{2+}:$ 257.2067).

O-tigloylcyclomicrophylline-A (4): white powder; ${ }^{1} \mathrm{H}$ NMR and ${ }^{13} \mathrm{C}$ NMR $(600 / 150 \mathrm{MHz}$, $\left.\mathrm{CD}_{3} \mathrm{OD}\right)$ see Table 2;

+ESI-QqTOF-MS $(m / z): 527.4220[\mathrm{M}+\mathrm{H}]^{+}, 264.2186[\mathrm{M}+2 \mathrm{H}]^{2+}\left(\right.$ calcd for $\mathrm{C}_{33} \mathrm{H}_{55} \mathrm{~N}_{2} \mathrm{O}_{3}{ }^{+}$: 527.4213, for $\mathrm{C}_{33} \mathrm{H}_{56} \mathrm{~N}_{2} \mathrm{O}_{3}{ }^{2+}$ : 264.2146).

Cyclomicrophylline-A (5): white powder; ${ }^{1} \mathrm{H} \mathrm{NMR}\left(600 \mathrm{MHz}, \mathrm{CD}_{3} \mathrm{OD} ; \delta\right.$ (ppm), intensity, mult., J (Hz)): 5.51 (1H, m, H-6), 5.48 (1H, m, H-7), 4.15 (1H, ddd, 9.4, 6.8, 2.2,

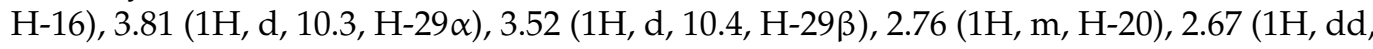
12.0, 3.5, H-3), 2.59 (1H, dd, 5.5, 2.5, H-8), 2.34 (6H, s, H-31/32), 2.29 (6H, s, H-33/34), 2.03 $(1 \mathrm{H}, \mathrm{m}, \mathrm{H}-15 \alpha), 1.94(1 \mathrm{H}, \mathrm{d}, 2.6, \mathrm{H}-5), 1.89$ (1H, m, H-11 $\alpha), 1.88(1 \mathrm{H}, \mathrm{m}, \mathrm{H}-17), 1.81(1 \mathrm{H}$, m, H-2 $\alpha), 1.72$ (1H, m, H-12 $\alpha), 1.65$ (1H, m, H-2 $\beta), 1.61$ (2H, m, H-1), 1.48 (1H, ddd, 15.1,

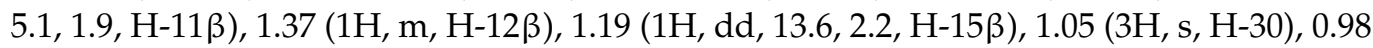
(3H, s, H-28), 0.96 (3H, s, H-18), 0.93 (3H, d, 6.6, H-21), 0.78 (1H, d, 4.1, H-19 $),-0.10$ (1H, d, 4.1, H-19ß);

${ }^{13} \mathrm{C}$ NMR (150 MHz, CD $\left.3 \mathrm{OD} ; \delta(\mathrm{ppm})\right): 130.60(\mathrm{CH}, \mathrm{C}-7), 126.75(\mathrm{CH}, \mathrm{C}-6), 80.17(\mathrm{CH}$, C-16), 73.21 (CH, C-3), $73.08\left(\mathrm{CH}_{2}, \mathrm{C}-29\right), 63.88$ (CH, C-20), 57.77 (CH, C-17), 50.93 (qC, 
C-14), 46.31 (qC, C-13), $45.92(\mathrm{CH}, \mathrm{C}-5), 44.51(\mathrm{CH}, \mathrm{C}-8), 44.50\left(\mathrm{CH}_{3}, \mathrm{C}-33 / 34\right), 43.36(\mathrm{qC}$, $\mathrm{C}-4), 42.97\left(\mathrm{CH}_{3}, \mathrm{C}-31 / 32\right), 42.39\left(\mathrm{CH}_{2}, \mathrm{C}-15\right), 32.95\left(\mathrm{CH}_{2}, \mathrm{C}-12\right), 31.79\left(\mathrm{CH}_{2}, \mathrm{C}-1\right), 29.16$ (qC, C-10), $25.74\left(\mathrm{CH}_{2}, \mathrm{C}-11\right), 21.91(\mathrm{qC}, \mathrm{C}-9), 19.54\left(\mathrm{CH}_{2}, \mathrm{C}-2\right), 19.24\left(\mathrm{CH}_{2}, \mathrm{C}-19\right), 19.20$ $\left(\mathrm{CH}_{3}, \mathrm{C}-28\right), 15.70\left(\mathrm{CH}_{3}, \mathrm{C}-18\right), 12.81\left(\mathrm{CH}_{3}, \mathrm{C}-30\right), 10.53\left(\mathrm{CH}_{3}, \mathrm{C}-21\right)$.

+ ESI-QqTOF-MS $(m / z): 445.3835[\mathrm{M}+\mathrm{H}]^{+}, 223.1989[\mathrm{M}+2 \mathrm{H}]^{2+}\left(\right.$ calcd for $\mathrm{C}_{28} \mathrm{H}_{49} \mathrm{~N}_{2} \mathrm{O}_{2}{ }^{+}$: 445.3794, for $\mathrm{C}_{28} \mathrm{H}_{50} \mathrm{~N}_{2} \mathrm{O}_{2}{ }^{2+}$ : 223.1936).

Cyclomicrophyllidine-A (6): colorless gum; ${ }^{1} \mathrm{H}$ NMR $\left(600 \mathrm{MHz}, \mathrm{CD}_{3} \mathrm{OD} ; \delta(\mathrm{ppm})\right.$, intensity, mult., J (Hz)): $8.00\left(2 \mathrm{H}, \mathrm{m}, \mathrm{H}-2^{\prime} / 6^{\prime}\right), 7.59\left(1 \mathrm{H}, \mathrm{m}, \mathrm{H}-4^{\prime}\right), 7.47\left(2 \mathrm{H}, \mathrm{m}, \mathrm{H}-3^{\prime} / 5^{\prime}\right), 5.49$ $(1 \mathrm{H}, \mathrm{m}, \mathrm{H}-6), 5.46(1 \mathrm{H}, \mathrm{m}, \mathrm{H}-7), 5.34(1 \mathrm{H}, \mathrm{ddd}, 8.6,5.9,1.1, \mathrm{H}-16), 3.80(1 \mathrm{H}, \mathrm{m}, \mathrm{H}-29 \alpha), 3.51$ $(1 \mathrm{H}, \mathrm{m}, \mathrm{H}-29 \beta), 2.66(1 \mathrm{H}, \mathrm{m}, \mathrm{H}-20), 2.66(1 \mathrm{H}, \mathrm{m}, \mathrm{H}-3), 2.59(1 \mathrm{H}, \mathrm{dd}, 5.4,2.5, \mathrm{H}-8), 2.35(1 \mathrm{H}$, m, H-17), 2.34 (6H, s, H-31/32), $2.16(1 \mathrm{H}, \mathrm{m}, \mathrm{H}-15 \alpha), 2.09$ (6H, s, H-33/34), $1.94(1 \mathrm{H}, \mathrm{br} \mathrm{s}$, $\mathrm{H}-5), 1.86(1 \mathrm{H}, \mathrm{m}, \mathrm{H}-11 \alpha), 1.82(1 \mathrm{H}, \mathrm{m}, \mathrm{H}-2 \alpha), 1.72(1 \mathrm{H}, \mathrm{dd}, 13.3,5.1, \mathrm{H}-12 \alpha), 1.64(1 \mathrm{H}, \mathrm{m}$, $\mathrm{H}-2 \beta), 1.61(2 \mathrm{H}, \mathrm{m}, \mathrm{H}-1), 1.47(1 \mathrm{H}, \mathrm{m}, \mathrm{H}-11 \beta), 1.37(1 \mathrm{H}, \mathrm{ddd}, 13.1,5.6,1.9, \mathrm{H}-12 \beta), 1.24(1 \mathrm{H}$, $\mathrm{d}(\mathrm{d}), 14.2,(<1), \mathrm{H}-15 \beta), 1.05$ (3H, s, H-30), 1.04 (3H, s, H-28), 0.96 (3H, s, H-18), 0.90 (3H, d, 6.4, H-21), $0.78(1 \mathrm{H}, \mathrm{d}, 4.1, \mathrm{H}-19 \alpha),-0.10(1 \mathrm{H}, \mathrm{d}, 4.1, \mathrm{H}-19 \beta)$;

${ }^{13} \mathrm{C}$ NMR (150 MHz, CD 3 OD; $\delta(\mathrm{ppm})$ ): 167.64 (qC, OCO), 134.21 (CH, C-4'), 132.17 (qC, C-1' $), 130.60(\mathrm{CH}, \mathrm{C}-7), 130.32\left(\mathrm{CH}, \mathrm{C}-2^{\prime} / 6^{\prime}\right), 129.58\left(\mathrm{CH}, \mathrm{C}-3^{\prime} / 5^{\prime}\right), 126.75(\mathrm{CH}, \mathrm{C}-6)$, $81.87(\mathrm{CH}, \mathrm{C}-16), 73.19(\mathrm{CH}, \mathrm{C}-3), 73.11\left(\mathrm{CH}_{2}, \mathrm{C}-29\right), 61.36(\mathrm{CH}, \mathrm{C}-20), 56.95(\mathrm{CH}, \mathrm{C}-17)$, 50.93 (qC, C-14), 46.28 (qC, C-13), 45.93 (CH, C-5), 44.51 (CH, C-8), 43.36 (qC, C-4), 43.27 $\left(\mathrm{CH}_{2}, \mathrm{C}-15\right), 42.98\left(\mathrm{CH}_{3}, \mathrm{C}-31 / 32\right), 40.77\left(\mathrm{CH}_{3}, \mathrm{C}-33 / 34\right), 32.95\left(\mathrm{CH}_{2}, \mathrm{C}-12\right), 31.80\left(\mathrm{CH}_{2}\right.$, C-1), 29.17 (qC, C-10), $25.74\left(\mathrm{CH}_{2}, \mathrm{C}-11\right), 21.91(\mathrm{qC}, \mathrm{C}-9), 19.53\left(\mathrm{CH}_{2}, \mathrm{C}-2\right), 19.25\left(\mathrm{CH}_{2}\right.$, C-19), $18.30\left(\mathrm{CH}_{3}, \mathrm{C}-28\right), 15.70\left(\mathrm{CH}_{3}, \mathrm{C}-18\right), 12.81\left(\mathrm{CH}_{3}, \mathrm{C}-30\right), 10.49\left(\mathrm{CH}_{3}, \mathrm{C}-21\right)$.

+ ESI-QqTOF-MS $(m / z): 549.4043[\mathrm{M}+\mathrm{H}]^{+}, 275.2089[\mathrm{M}+2 \mathrm{H}]^{2+}\left(\right.$ calcd for $\mathrm{C}_{35} \mathrm{H}_{53} \mathrm{~N}_{2} \mathrm{O}_{3}{ }^{+}$: 549.4056, for $\mathrm{C}_{35} \mathrm{H}_{54} \mathrm{~N}_{2} \mathrm{O}_{3}{ }^{2+}:$ : 275.2067).

Cyclomicrophyllidine-B (7): colorless gum; ${ }^{1} \mathrm{H}$ NMR and ${ }^{13} \mathrm{C}$ NMR $(600 / 150 \mathrm{MHz}$, $\mathrm{CD}_{3} \mathrm{OD}$ ) see Table 2;

+ESI-QqTOF-MS $(m / z): 535.3964\left[\mathrm{M}+\mathrm{H}^{+}, 268.2029[\mathrm{M}+2 \mathrm{H}]^{2+}\left(\right.\right.$ calcd for $\mathrm{C}_{34} \mathrm{H}_{51} \mathrm{~N}_{2} \mathrm{O}_{3}{ }^{+}$: 535.3900, for $\mathrm{C}_{34} \mathrm{H}_{52} \mathrm{~N}_{2} \mathrm{O}_{3}{ }^{2+}$ : 268.1989).

O-benzoyl-cycloprotobuxoline-D (8): colorless gum; ${ }^{1} \mathrm{H}$ NMR and ${ }^{13} \mathrm{C}$ NMR $(600 / 150 \mathrm{MHz}$, $\mathrm{CD}_{3} \mathrm{OD}$ ) see Table 2;

+ESI-QqTOF-MS $(m / z): 507.4024[\mathrm{M}+\mathrm{H}]^{+}, 254.2062[\mathrm{M}+2 \mathrm{H}]^{2+}\left(\right.$ calcd for $\mathrm{C}_{33} \mathrm{H}_{51} \mathrm{~N}_{2} \mathrm{O}_{2}{ }^{+}$: 507.7830, for $\mathrm{C}_{33} \mathrm{H}_{52} \mathrm{~N}_{2} \mathrm{O}_{2}{ }^{2+}$ : 254.3955).

N-benzoyl-O-acetyl-cycloxo-buxoline-F (9): colorless gum; ${ }^{1} \mathrm{H}$ NMR $\left(600 \mathrm{MHz}, \mathrm{CD}_{3} \mathrm{OD}\right.$; $\delta(\mathrm{ppm})$, intensity, mult., J (Hz)): $7.75\left(2 \mathrm{H}, \mathrm{m}, \mathrm{H}-2^{\prime} / 6^{\prime}\right), 7.53\left(1 \mathrm{H}, \mathrm{m}, \mathrm{H}-4^{\prime}\right), 7.46(2 \mathrm{H}, \mathrm{m}$, H-3' $\left./ 5^{\prime}\right), 4.36(1 \mathrm{H}, \mathrm{dd}, 12.7,4.3, \mathrm{H}-3), 3.90(1 \mathrm{H}, \mathrm{m}, \mathrm{H}-29 \alpha), 3.77(1 \mathrm{H}, \mathrm{d}, 11.6, \mathrm{H}-29 \beta), 3.42$ (1H, m, H-20), $2.91(3 \mathrm{H}, \mathrm{s}, \mathrm{H}-33 / 34), 2.75(3 \mathrm{H}, \mathrm{s}, \mathrm{H}-33 / 34), 2.66(1 \mathrm{H}, \mathrm{s}, \mathrm{H}-12 \alpha), 2.47(1 \mathrm{H}, \mathrm{m}$, $\mathrm{H}-1 \alpha), 2.40(1 \mathrm{H}, \mathrm{m}, \mathrm{H}-12 \beta), 2.38$ (1H, m, H-17), $2.20(1 \mathrm{H}, \mathrm{m}, \mathrm{H}-8), 2.10(1 \mathrm{H}, \mathrm{m}, \mathrm{H}-5), 2.09$ $\left(3 \mathrm{H}, \mathrm{s}, \mathrm{Ac}-\mathrm{CH}_{3}\right), 2.06(1 \mathrm{H}, \mathrm{m}, \mathrm{H}-16 \alpha), 1.86(1 \mathrm{H}, \mathrm{dd}, 13.1,4.0, \mathrm{H}-2 \alpha), 1.73(1 \mathrm{H}, \mathrm{m}, \mathrm{H}-15 \alpha)$, $1.72(1 \mathrm{H}, \mathrm{m}, \mathrm{H}-2 \beta), 1.67(1 \mathrm{H}, \mathrm{m}, \mathrm{H}-15 \beta), 1.66(1 \mathrm{H}, \mathrm{m}, \mathrm{H}-16 \beta), 1.62(1 \mathrm{H}, \mathrm{m}, \mathrm{H}-7 \alpha), 1.60(1 \mathrm{H}$, $\mathrm{d}, 3.9, \mathrm{H}-19 \alpha), 1.56(1 \mathrm{H}, \mathrm{dd}, 13.3,3.9, \mathrm{H}-6 \alpha), 1.42(1 \mathrm{H}, \mathrm{m}, \mathrm{H}-7 \beta), 1.37(1 \mathrm{H}, \mathrm{m}, \mathrm{H}-1 \beta), 1.29$ $(3 \mathrm{H}, \mathrm{d}, 6.6, \mathrm{H}-21), 1.26(1 \mathrm{H}, \mathrm{d}, 3.9, \mathrm{H}-19 \beta), 1.15(1 \mathrm{H}, \mathrm{m}, \mathrm{H}-6 \beta), 1.14(3 \mathrm{H}, \mathrm{s}, \mathrm{H}-28), 0.96(3 \mathrm{H}, \mathrm{s}$, $\mathrm{H}-18), 0.90$ (3H, s, H-30);

${ }^{13} \mathrm{C}$ NMR (150 MHz, CD $\mathrm{OD} ; \delta$ (ppm)): 212.85 (qC, C-11), 173.10 (qC, Ac-CO), 170.67 (qC, OCNH), $136.35\left(\mathrm{qC}, \mathrm{C}-1^{\prime}\right), 132.47\left(\mathrm{CH}, \mathrm{C}-4^{\prime}\right), 129.45\left(\mathrm{CH}, \mathrm{C}-3^{\prime} / 5^{\prime}\right), 128.42\left(\mathrm{CH}, \mathrm{C}-2^{\prime} / 6^{\prime}\right)$, $67.16(\mathrm{CH}, \mathrm{C}-20), 66.98\left(\mathrm{CH}_{2}, \mathrm{C}-29\right), 52.74\left(\mathrm{CH}_{2}, \mathrm{C}-12\right), 52.42(\mathrm{CH}, \mathrm{C}-3), 49.79$ (qC, C-14), 48.09 (CH, C-17), 47.01 (qC, C-13), 44.37 (qC, C-4), $43.57\left(\mathrm{CH}_{3}, \mathrm{C}-33 / 34\right), 42.90(\mathrm{CH}, \mathrm{C}-5)$, 42.79 (CH, C-8), 39.29 (qC, C-10), $35.96\left(\mathrm{CH}_{3}, \mathrm{C}-33 / 34\right), 35.19$ (qC, C-9), $35.05\left(\mathrm{CH}_{2}, \mathrm{C}-15\right)$, $32.13\left(\mathrm{CH}_{2}, \mathrm{C}-19\right), 29.13\left(\mathrm{CH}_{2}, \mathrm{C}-1\right), 28.33\left(\mathrm{CH}_{2}, \mathrm{C}-2\right), 26.23\left(\mathrm{CH}_{2}, \mathrm{C}-16\right), 25.72\left(\mathrm{CH}_{2}, \mathrm{C}-7\right)$, $20.94\left(\mathrm{CH}_{3}, \mathrm{Ac}-\mathrm{CH}_{3}\right), 19.83\left(\mathrm{CH}_{2}, \mathrm{C}-6\right), 19.34\left(\mathrm{CH}_{3}, \mathrm{C}-28\right), 17.24\left(\mathrm{CH}_{3}, \mathrm{C}-18\right), 11.98\left(\mathrm{CH}_{3}\right.$, $\mathrm{C}-30), 11.65\left(\mathrm{CH}_{3}, \mathrm{C}-21\right)$.

+ESI-QqTOF-MS $(m / z): 563.3939[\mathrm{M}+\mathrm{H}]^{+}, 282.2024[\mathrm{M}+2 \mathrm{H}]^{2+}\left(\right.$ calcd for $\mathrm{C}_{35} \mathrm{H}_{51} \mathrm{~N}_{2} \mathrm{O}_{4}{ }^{+}$: 563.3849, for $\mathrm{C}_{35} \mathrm{H}_{52} \mathrm{~N}_{2} \mathrm{O}_{4}{ }^{2+}:$ 282.1964); MS/MS (m/z): $518\left[\mathrm{M}-\left(\mathrm{CH}_{3}\right)_{2} \mathrm{NH}\right]^{+}, 476$ [518$\left.\mathrm{CH}_{2}=\mathrm{CO}\right]^{+}, 458\left[476-\mathrm{H}_{2} \mathrm{O}^{+}, 122\left[\mathrm{C}_{6} \mathrm{H}_{5} \mathrm{CONH}_{3}\right]^{+}, 105\left[\mathrm{C}_{6} \mathrm{H}_{5} \mathrm{CO}\right]^{+}\right.$. 
N-benzoyl-cycloxo-buxoline-F (10): colorless gum; ${ }^{1} \mathrm{H}$ NMR $\left(600 \mathrm{MHz}, \mathrm{CD}_{3} \mathrm{OD} ; \delta\right.$ (ppm), intensity, mult., J (Hz)): $7.83\left(2 \mathrm{H}, \mathrm{m}, \mathrm{H}-2^{\prime} / 6^{\prime}\right), 7.55\left(1 \mathrm{H}, \mathrm{m}, \mathrm{H}-4^{\prime}\right), 7.47(2 \mathrm{H}, \mathrm{m}$, H-3 $\left.{ }^{\prime} / 5^{\prime}\right), 4.15(1 \mathrm{H}, \mathrm{dd}, 12.6,4.0, \mathrm{H}-3), 3.41(1 \mathrm{H}, \mathrm{m}, \mathrm{H}-20), 3.39(1 \mathrm{H}, \mathrm{m}, \mathrm{H}-29 \alpha), 3.13(1 \mathrm{H}, \mathrm{d}$, 12.7, H-29ß), 2.91 (3H, s, H-33/34), $2.75(3 \mathrm{H}, \mathrm{s}, \mathrm{H}-33 / 34), 2.65(1 \mathrm{H}, \mathrm{m}, \mathrm{H}-12 \alpha), 2.43(1 \mathrm{H}, \mathrm{m}$, $\mathrm{H}-1 \alpha), 2.40(1 \mathrm{H}, \mathrm{m}, \mathrm{H}-12 \beta), 2.38$ (1H, m, H-17), $2.20(1 \mathrm{H}, \mathrm{m}, \mathrm{H}-8), 2.09(1 \mathrm{H}, \mathrm{m}, \mathrm{H}-5), 2.06$

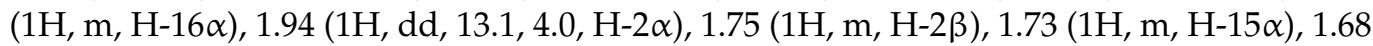
$(1 \mathrm{H}, \mathrm{m}, \mathrm{H}-6 \alpha), 1.66(1 \mathrm{H}, \mathrm{m}, \mathrm{H}-15 \beta), 1.64(1 \mathrm{H}, \mathrm{m}, \mathrm{H}-16 \beta), 1.62(1 \mathrm{H}, \mathrm{m}, \mathrm{H}-7 \alpha), 1.61(1 \mathrm{H}, \mathrm{d}$, 3.8, H-19 $\alpha), 1.48(1 \mathrm{H}, \mathrm{m}, \mathrm{H}-7 \beta), 1.34(1 \mathrm{H}, \mathrm{m}, \mathrm{H}-1 \beta), 1.29(3 \mathrm{H}, \mathrm{d}, 5.4, \mathrm{H}-21), 1.26(1 \mathrm{H}, \mathrm{d}, 3.9$, H-19ß), 1.14 (3H, s, H-28), 1.07 (1H, m, H-6ß), 0.95 (3H, s, H-18), 0.72 (3H, s, H-30);

${ }^{13} \mathrm{C}$ NMR $\left(150 \mathrm{MHz}, \mathrm{CD}_{3} \mathrm{OD} ; \delta(\mathrm{ppm})\right): 212.87(\mathrm{qC}, \mathrm{C}-11), 171.59(\mathrm{qC}, \mathrm{OCNH}), 135.42$ (qC, C-1' $), 132.83\left(\mathrm{CH}, \mathrm{C}-4^{\prime}\right), 129.57\left(\mathrm{CH}, \mathrm{C}-3^{\prime} / 5^{\prime}\right), 128.53\left(\mathrm{CH}, \mathrm{C}-2^{\prime} / 6^{\prime}\right), 67.19(\mathrm{CH}, \mathrm{C}-20)$, $65.18\left(\mathrm{CH}_{2}, \mathrm{C}-29\right), 53.36(\mathrm{CH}, \mathrm{C}-3), 52.78\left(\mathrm{CH}_{2}, \mathrm{C}-12\right), 49.90(\mathrm{qC}, \mathrm{C}-14), 48.09(\mathrm{CH}, \mathrm{C}-17)$, 47.08 (qC, C-13), 45.88 (qC, C-4), $43.56\left(\mathrm{CH}_{3}, \mathrm{C}-33 / 34\right), 42.79(\mathrm{CH}, \mathrm{C}-5), 42.34(\mathrm{CH}, \mathrm{C}-8)$, $39.52(\mathrm{qC}, \mathrm{C}-10), 35.96\left(\mathrm{CH}_{3}, \mathrm{C}-33 / 34\right), 35.42(\mathrm{qC}, \mathrm{C}-9), 34.96\left(\mathrm{CH}_{2}, \mathrm{C}-15\right), 31.65\left(\mathrm{CH}_{2}, \mathrm{C}-19\right)$, $29.27\left(\mathrm{CH}_{2}, \mathrm{C}-1\right), 27.79\left(\mathrm{CH}_{2}, \mathrm{C}-2\right), 26.23\left(\mathrm{CH}_{2}, \mathrm{C}-16\right), 25.46\left(\mathrm{CH}_{2}, \mathrm{C}-7\right), 19.49\left(\mathrm{CH}_{2}, \mathrm{C}-6\right)$, $19.34\left(\mathrm{CH}_{3}, \mathrm{C}-28\right), 17.22\left(\mathrm{CH}_{3}, \mathrm{C}-18\right), 11.90\left(\mathrm{CH}_{3}, \mathrm{C}-30\right), 11.65\left(\mathrm{CH}_{3}, \mathrm{C}-21\right)$.

+ ESI-QqTOF-MS $(m / z): 521.3766[\mathrm{M}+\mathrm{H}]^{+}, 261.1941[\mathrm{M}+2 \mathrm{H}]^{2+}\left(\right.$ calcd for $\mathrm{C}_{33} \mathrm{H}_{49} \mathrm{~N}_{2} \mathrm{O}_{3}{ }^{+}$: 521.7660, for $\left.\mathrm{C}_{33} \mathrm{H}_{50} \mathrm{~N}_{2} \mathrm{O}_{3}{ }^{2+}: 261.387\right)$; MS/MS $(\mathrm{m} / z)$ : $476\left[\mathrm{M}-\left(\mathrm{CH}_{3}\right)_{2} \mathrm{NH}\right]^{+}, 458\left[476-\mathrm{H}_{2} \mathrm{O}\right]^{+}$, $122\left[\mathrm{C}_{6} \mathrm{H}_{5} \mathrm{CONH}_{3}\right]^{+}, 105\left[\mathrm{C}_{6} \mathrm{H}_{5} \mathrm{CO}\right]^{+}$.

29-hydroxy-cyclomikuranine-L (11): colorless gum; ${ }^{1} \mathrm{H}$ NMR and ${ }^{13} \mathrm{C}$ NMR $(600 / 150 \mathrm{MHz}$, $\mathrm{CD}_{3} \mathrm{OD}$ ) see Table 3;

+ESI-QqTOF-MS $(m / z)$ : $418.3362\left[\mathrm{M}+\mathrm{H}^{+}\right.$(calcd for $\mathrm{C}_{26} \mathrm{H}_{44} \mathrm{NO}_{3}{ }^{+}:$418.3321).

$\mathrm{N}_{\mathrm{b}}$-dimethylcycloxobuxoviricine (12): white powder; ${ }^{1} \mathrm{H} \mathrm{NMR}\left(600 \mathrm{MHz}, \mathrm{CD}_{3} \mathrm{OD} ; \delta\right.$ (ppm), intensity, mult., J (Hz)): $6.96(1 \mathrm{H}, \mathrm{d}, 10.1, \mathrm{H}-1), 5.92(1 \mathrm{H}, \mathrm{d}, 10.1, \mathrm{H}-2), 4.32(1 \mathrm{H}$, ddd, 9.4, 7.4, 2.1, H-16), 3.59 (1H, m, H-20), $2.96(3 \mathrm{H}, \mathrm{s}, \mathrm{H}-33 / 34), 2.81(3 \mathrm{H}, \mathrm{s}, \mathrm{H}-33 / 34), 2.23(1 \mathrm{H}$, $\mathrm{dd}, 11.1,7.4, \mathrm{H}-17), 2.15$ (1H, dd, 11.1, 7.4, H-5), $2.10(1 \mathrm{H}, \mathrm{m}, \mathrm{H}-11 \alpha), 2.05(1 \mathrm{H}, \mathrm{m}, \mathrm{H}-15 \alpha)$, $2.00(1 \mathrm{H}, \mathrm{dd}, 10.1,6.8, \mathrm{H}-8), 1.88(1 \mathrm{H}, \mathrm{m}, \mathrm{H}-12 \alpha), 1.67(1 \mathrm{H}, \mathrm{m}, \mathrm{H}-11 \beta), 1.62(1 \mathrm{H}, \mathrm{m}, \mathrm{H}-6 \alpha)$, $1.62(1 \mathrm{H}, \mathrm{m}, \mathrm{H}-12 \beta), 1.56(1 \mathrm{H}, \mathrm{m}, \mathrm{H}-7 \alpha), 1.44(1 \mathrm{H}, \mathrm{dd}, 13.8,2.1, \mathrm{H}-15 \beta), 1.39(1 \mathrm{H}, \mathrm{d}, 4.7$, $\mathrm{H}-19 \alpha), 1.32(3 \mathrm{H}, \mathrm{d}, 6.6, \mathrm{H}-21), 1.30(1 \mathrm{H}, \mathrm{m}, \mathrm{H}-7 \beta), 1.21(3 \mathrm{H}, \mathrm{s}, \mathrm{H}-28), 1.16(1 \mathrm{H}, \mathrm{dd}, 12.8,4.0$, H-6ß), 1.09 (3H, s, H-29), 1.08 (3H, s, H-18), 0.97 (3H, s, H-30), 0.88 (1H, d, 4.7, H-19ß);

${ }^{13} \mathrm{C}$ NMR (150 MHz, CD 3 OD; $\left.\delta(\mathrm{ppm})\right): 207.60$ (qC, C-3), $156.58(\mathrm{CH}, \mathrm{C}-1), 127.19(\mathrm{CH}$, C-2), $76.92(\mathrm{CH}, \mathrm{C}-16), 68.12(\mathrm{CH}, \mathrm{C}-20), 56.08$ (CH, C-17), 49.38 (qC, C-14), 47.40 (qC, C-13), 47.18 (qC, C-4), $46.97\left(\mathrm{CH}_{2}, \mathrm{C}-15\right), 46.06(\mathrm{CH}, \mathrm{C}-5), 45.31(\mathrm{CH}, \mathrm{C}-8), 43.69\left(\mathrm{CH}_{3}, \mathrm{C}-33 / 34\right)$, $36.55\left(\mathrm{CH}_{3}, \mathrm{C}-33 / 34\right), 32.33\left(\mathrm{CH}_{2}, \mathrm{C}-12\right), 31.41(\mathrm{qC}, \mathrm{C}-10), 30.88\left(\mathrm{CH}_{2}, \mathrm{C}-19\right), 28.15\left(\mathrm{CH}_{2}\right.$, C-11), 25.41 (qC, C-9), $24.88\left(\mathrm{CH}_{2}, \mathrm{C}-7\right), 21.86\left(\mathrm{CH}_{3}, \mathrm{C}-29\right), 20.61\left(\mathrm{CH}_{2}, \mathrm{C}-6\right), 20.50\left(\mathrm{CH}_{3}\right.$, $\mathrm{C}-28), 19.62\left(\mathrm{CH}_{3}, \mathrm{C}-30\right), 18.48\left(\mathrm{CH}_{3}, \mathrm{C}-18\right), 11.48\left(\mathrm{CH}_{3}, \mathrm{C}-21\right)$.

+ESI-QqTOF-MS ( $\mathrm{m} / \mathrm{z})$ : $400.3291[\mathrm{M}+\mathrm{H}]^{+}$(calcd for $\left.\mathrm{C}_{26} \mathrm{H}_{42} \mathrm{NO}_{2}{ }^{+}: 400.3216\right)$.

(E)-cyclobuxophyllinine-M (13) and (Z)-cyclobuxophyllinine-M (14) (93.5\%:6.5\%): white powder; ${ }^{1} \mathrm{H} \mathrm{NMR}\left(600 \mathrm{MHz}, \mathrm{CDCl}_{3} ; \delta(\mathrm{ppm})\right.$, intensity, mult., J $\left.(\mathrm{Hz})\right): 6.58(1 \mathrm{H}, \mathrm{q}$, 7.5, H-20 (E)), $5.74(1 \mathrm{H}, \mathrm{q}, 7.4, \mathrm{H}-20(\mathrm{Z})), 2.75(3 \mathrm{H}, \mathrm{s}, \mathrm{H}-31 / 32), 2.64(1 \mathrm{H}, \mathrm{m}, \mathrm{H}-3), 2.19(1 \mathrm{H}$,

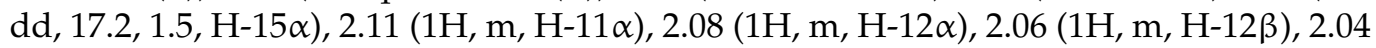
$(1 \mathrm{H}, \mathrm{m}, \mathrm{H}-2 \alpha), 2.01(1 \mathrm{H}, \mathrm{m}, \mathrm{H}-15 \beta), 1.87(1 \mathrm{H}, \mathrm{m}, \mathrm{H}-2 \beta), 1.84(3 \mathrm{H}, \mathrm{d}, 7.6, \mathrm{H}-21), 1.68(1 \mathrm{H}, \mathrm{m}$, $\mathrm{H}-6 \alpha), 1.66(1 \mathrm{H}, \mathrm{m}, \mathrm{H}-8), 1.57(1 \mathrm{H}, \mathrm{m}, \mathrm{H}-1 \alpha), 1.43(1 \mathrm{H}, \mathrm{m}, \mathrm{H}-1 \beta), 1.41(1 \mathrm{H}, \mathrm{m}, \mathrm{H}-5), 1.38$ $(1 \mathrm{H}, \mathrm{m}, \mathrm{H}-7 \alpha), 1.33(3 \mathrm{H}, \mathrm{s}, \mathrm{H}-18), 1.29(1 \mathrm{H}, \mathrm{m}, \mathrm{H}-11 \beta), 1.16(3 \mathrm{H}, \mathrm{s}, \mathrm{H}-29), 1.11(1 \mathrm{H}, \mathrm{qd}, 12.6$, 2.5, H-7 3$), 0.98(3 \mathrm{H}, \mathrm{s}, \mathrm{H}-30), 0.94(3 \mathrm{H}, \mathrm{s}, \mathrm{H}-28), 0.84(1 \mathrm{H}, \mathrm{qd}, 12.7,2.4, \mathrm{H}-6 \beta), 0.67(1 \mathrm{H}, \mathrm{d}$, 4.6, H-19 $\alpha), 0.49(1 \mathrm{H}, \mathrm{d}, 4.6, \mathrm{H}-19 \beta)$;

${ }^{13} \mathrm{C}$ NMR $\left(150 \mathrm{MHz}, \mathrm{CDCl}_{3} ; \delta(\mathrm{ppm})\right): 206.60$ (qC, C-16), 146.59 (qC, C-17), $132.23(\mathrm{CH}$, C-20 (Z)), $130.62(\mathrm{CH}, \mathrm{C}-20(\mathrm{E})), 69.81(\mathrm{CH}, \mathrm{C}-3), 49.43\left(\mathrm{CH}_{2}, \mathrm{C}-15\right), 48.07(\mathrm{CH}, \mathrm{C}-5), 46.76$ (qC, C-13), $45.78(\mathrm{CH}, \mathrm{C}-8), 42.48$ (qC, C-14), $39.42(\mathrm{qC}, \mathrm{C}-4), 32.87\left(\mathrm{CH}_{3}, \mathrm{C}-31 / 32\right), 31.84$ $\left(\mathrm{CH}_{2}, \mathrm{C}-1\right), 30.27\left(\mathrm{CH}_{2}, \mathrm{C}-19\right), 29.36\left(\mathrm{CH}_{2}, \mathrm{C}-12\right), 26.20\left(\mathrm{CH}_{2}, \mathrm{C}-7\right), 26.12(\mathrm{qC}, \mathrm{C}-10), 26.04$ $\left(\mathrm{CH}_{2}, \mathrm{C}-11\right), 25.36\left(\mathrm{CH}_{3}, \mathrm{C}-29\right), 24.40\left(\mathrm{CH}_{3}, \mathrm{C}-18\right), 23.73\left(\mathrm{CH}_{2}, \mathrm{C}-2\right), 21.03\left(\mathrm{CH}_{3}, \mathrm{C}-28\right), 20.89$ $\left(\mathrm{CH}_{2}, \mathrm{C}-6\right), 19.88(\mathrm{qC}, \mathrm{C}-9), 15.02\left(\mathrm{CH}_{3}, \mathrm{C}-30\right), 13.39\left(\mathrm{CH}_{3}, \mathrm{C}-21\right)$.

+ESI-QqTOF-MS $(\mathrm{m} / \mathrm{z}): 370.3182[\mathrm{M}+\mathrm{H}]^{+}\left(\right.$calcd for $\left.\mathrm{C}_{25} \mathrm{H}_{40} \mathrm{NO}^{+}: 370.3110\right)$. 
(E)-cyclosuffrobuxinine-M (15) and (Z)-cyclosuffrobuxinine-M (16) (69.9\%:30.1\%): light yellow gum; ${ }^{1} \mathrm{H}$ NMR $\left(600 \mathrm{MHz}, \mathrm{CDCl}_{3} ; \delta(\mathrm{ppm})\right.$, intensity, mult., $\left.\mathrm{J}(\mathrm{Hz})\right): 6.63(1 \mathrm{H}, \mathrm{q}$, 7.5, H-20 (E)), $5.78(1 \mathrm{H}, \mathrm{q}, 7.3, \mathrm{H}-20(\mathrm{Z})), 4.92(1 \mathrm{H}, \mathrm{s}, \mathrm{H}-29 \alpha), 4.87(1 \mathrm{H}, \mathrm{s}, \mathrm{H}-29 \beta), 3.56(1 \mathrm{H}$, $\mathrm{m}, \mathrm{H}-3), 2.85(3 \mathrm{H}, \mathrm{s}, \mathrm{H}-31 / 32), 2.32(1 \mathrm{H}, \mathrm{m}, \mathrm{H}-2 \alpha), 2.26(1 \mathrm{H}, \mathrm{m}, \mathrm{H}-15 \alpha(\mathrm{Z})), 2.23(1 \mathrm{H}, \mathrm{m}$, H-15 $\alpha(E)), 2.20(1 \mathrm{H}, \mathrm{m}, \mathrm{H}-11 \alpha(E)), 2.15(1 \mathrm{H}, \mathrm{d}, 4.2, \mathrm{H}-5), 2.12(3 \mathrm{H}, \mathrm{d}, 7.4, \mathrm{H}-21(\mathrm{Z})), 2.10$ $(1 \mathrm{H}, \mathrm{m}, \mathrm{H}-11 \alpha(\mathrm{Z})), 2.10(2 \mathrm{H}, \mathrm{m}, \mathrm{H}-12 \alpha(E)), 2.06(1 \mathrm{H}, \mathrm{m}, \mathrm{H}-15 \beta(E)), 2.03(1 \mathrm{H}, \mathrm{m}, \mathrm{H}-15 \beta$ (Z)), $1.85(3 \mathrm{H}, \mathrm{d}, 7.5, \mathrm{H}-21(\mathrm{E})), 1.81(1 \mathrm{H}, \mathrm{m}, \mathrm{H}-1 \alpha), 1.75(1 \mathrm{H}, \mathrm{dd}, 12.4,4.7, \mathrm{H}-8), 1.72(1 \mathrm{H}, \mathrm{m}$, H-12 $\beta(\mathrm{Z})), 1.60(1 \mathrm{H}, \mathrm{m}, \mathrm{H}-2 \beta), 1.57(1 \mathrm{H}, \mathrm{m}, \mathrm{H}-6 \alpha), 1.51(1 \mathrm{H}, \mathrm{m}, \mathrm{H}-1 \beta), 1.42(1 \mathrm{H}, \mathrm{m}, \mathrm{H}-7 \alpha)$, $1.37(1 \mathrm{H}, \mathrm{m}, \mathrm{H}-11 \beta), 1.33(3 \mathrm{H}, \mathrm{s}, \mathrm{H}-18(E)), 1.25(3 \mathrm{H}, \mathrm{s}, \mathrm{H}-18(\mathrm{Z})), 1.19(1 \mathrm{H}, \mathrm{dd}, 12.6,2.3$, H-7 $\beta), 1.09$ (1H, qd, 12.7, 2.3, H-6ß), $0.98(3 \mathrm{H}, \mathrm{s}, \mathrm{H}-28(E)), 0.95(3 \mathrm{H}, \mathrm{s}, \mathrm{H}-28(\mathrm{Z})), 0.44(1 \mathrm{H}$, d, 4.5, H-19 $\alpha), 0.22(1 \mathrm{H}, \mathrm{d}, 4.7, \mathrm{H}-19 \beta(E)), 0.19(1 \mathrm{H}, \mathrm{d}, 4.8, \mathrm{H}-19 \beta(Z))$;

${ }^{13} \mathrm{C} \mathrm{NMR}\left(150 \mathrm{MHz}, \mathrm{CDCl}_{3} ; \delta(\mathrm{ppm})\right): 209.46(\mathrm{qC}, \mathrm{C}-16(\mathrm{Z})), 207.28(\mathrm{qC}, \mathrm{C}-16(E))$, 146.72 (qC, C-17 (Z)), 146.51 (qC, C-4 (Z)), 146.46 (qC, C-4 (E)), 146.45 (qC, C-17 (E)), 132.91 $(\mathrm{CH}, \mathrm{C}-20(\mathrm{Z})), 131.46(\mathrm{CH}, \mathrm{C}-20(\mathrm{E})), 104.37\left(\mathrm{CH}_{2}, \mathrm{C}-29(\mathrm{Z})\right), 104.36\left(\mathrm{CH}_{2}, \mathrm{C}-29(\mathrm{E})\right), 62.83$ $(\mathrm{CH}, \mathrm{C}-3(\mathrm{Z})), 62.81(\mathrm{CH}, \mathrm{C}-3(\mathrm{E})), 50.76\left(\mathrm{CH}_{2}, \mathrm{C}-15(\mathrm{Z})\right), 49.30\left(\mathrm{CH}_{2}, \mathrm{C}-15(E)\right), 46.84(\mathrm{qC}$, C-13 (E)), $46.74(\mathrm{qC}, \mathrm{C}-13(\mathrm{Z})), 45.40(\mathrm{CH}, \mathrm{C}-8(E)), 45.38(\mathrm{CH}, \mathrm{C}-8(\mathrm{Z})), 44.26(\mathrm{CH}, \mathrm{C}-5(E))$, $44.18(\mathrm{CH}, \mathrm{C}-5(\mathrm{Z})), 42.58(\mathrm{qC}, \mathrm{C}-14(\mathrm{E})), 42.11(\mathrm{qC}, \mathrm{C}-14(\mathrm{Z})), 31.79\left(\mathrm{CH}_{3}, \mathrm{C}-31 / 32(\mathrm{Z})\right)$, $31.77\left(\mathrm{CH}_{3}, \mathrm{C}-31 / 32(\mathrm{E})\right), 31.65(\mathrm{qC}, \mathrm{C}-10), 31.03\left(\mathrm{CH}_{2}, \mathrm{C}-1(E)\right), 30.95\left(\mathrm{CH}_{2}, \mathrm{C}-1(\mathrm{Z})\right), 30.66$ $\left(\mathrm{CH}_{2}, \mathrm{C}-2\right), 29.32\left(\mathrm{CH}_{2}, \mathrm{C}-12(E)\right), 28.50\left(\mathrm{CH}_{2}, \mathrm{C}-12(\mathrm{Z})\right), 27.92\left(\mathrm{CH}_{2}, \mathrm{C}-19(E)\right), 27.83\left(\mathrm{CH}_{2}\right.$, C-19 (Z)), $26.65\left(\mathrm{CH}_{2}, \mathrm{C}-11(\mathrm{E})\right), 26.48\left(\mathrm{CH}_{2}, \mathrm{C}-11(\mathrm{Z})\right), 26.40\left(\mathrm{CH}_{3}, \mathrm{C}-18(\mathrm{Z})\right), 25.35\left(\mathrm{CH}_{2}\right.$, C-7 (E)), $25.25\left(\mathrm{CH}_{2}, \mathrm{C}-7(\mathrm{Z})\right), 24.30\left(\mathrm{CH}_{3}, \mathrm{C}-18(E)\right), 23.55(\mathrm{qC}, \mathrm{C}-9(\mathrm{Z})), 23.41$ (qC, C-9 (E)), $23.24\left(\mathrm{CH}_{2}, \mathrm{C}-6(\mathrm{E})\right), 23.14\left(\mathrm{CH}_{2}, \mathrm{C}-6(\mathrm{Z})\right), 20.99\left(\mathrm{CH}_{3}, \mathrm{C}-28(E)\right), 20.59\left(\mathrm{CH}_{3}, \mathrm{C}-28(\mathrm{Z})\right), 14.40$ $\left(\mathrm{CH}_{3}, \mathrm{C}-21(\mathrm{Z})\right), 13.46\left(\mathrm{CH}_{3}, \mathrm{C}-21(\mathrm{E})\right)$.

+ESI-QqTOF-MS $(m / z)$ : $354.2848[\mathrm{M}+\mathrm{H}]^{+}$(calcd for $\left.\mathrm{C}_{24} \mathrm{H}_{36} \mathrm{NO}^{+}: 354.2797\right)$.

Cyclomicrobuxinine (17): light yellow powder; ${ }^{1} \mathrm{H} \mathrm{NMR}\left(600 \mathrm{MHz}, \mathrm{CDCl}_{3} ; \delta(\mathrm{ppm})\right.$, intensity, mult., J (Hz)): $4.90(1 \mathrm{H}, \mathrm{ddd}, 9.5,6.6,2.0, \mathrm{H}-16), 4.85(1 \mathrm{H}, \mathrm{s}, \mathrm{H}-29 \alpha), 4.61(1 \mathrm{H}, \mathrm{s}$, H-29ß), 3.02 (1H, d, 6.6, H-17), 2.95 (1H, dd, 11.8, 4.2, H-3), 2.53 (3H, s, H-31/32), 2.19 (1H, $\mathrm{m}, \mathrm{H}-11 \alpha), 2.17(1 \mathrm{H}, \mathrm{m}, \mathrm{H}-2 \alpha), 2.15(3 \mathrm{H}, \mathrm{s}, \mathrm{H}-21), 2.10$ (1H, m, H-5), $2.02(1 \mathrm{H}, \mathrm{m}, \mathrm{H}-12 \alpha)$, $1.94(1 \mathrm{H}, \mathrm{m}, \mathrm{H}-15 \alpha), 1.76(1 \mathrm{H}, \mathrm{m}, \mathrm{H}-1 \alpha), 1.71(1 \mathrm{H}, \mathrm{m}, \mathrm{H}-12 \beta), 1.54(1 \mathrm{H}, \mathrm{m}, \mathrm{H}-8), 1.51(1 \mathrm{H}$, $\mathrm{m}, \mathrm{H}-6 \alpha), 1.43(1 \mathrm{H}, \mathrm{dd}, 13.9,2.0, \mathrm{H}-15 \beta), 1.36(1 \mathrm{H}, \mathrm{m}, \mathrm{H}-7 \alpha), 1.34(1 \mathrm{H}, \mathrm{m}, \mathrm{H}-1 \beta), 1.26(1 \mathrm{H}$, $\mathrm{m}, \mathrm{H}-11 \beta), 1.23(1 \mathrm{H}, \mathrm{m}, \mathrm{H}-2 \beta), 1.21(3 \mathrm{H}, \mathrm{s}, \mathrm{H}-28), 1.17(1 \mathrm{H}, \mathrm{m}, \mathrm{H}-7 \beta), 1.04(1 \mathrm{H}, \mathrm{m}, \mathrm{H}-6 \beta)$, $0.90(3 \mathrm{H}, \mathrm{s}, \mathrm{H}-18), 0.31(1 \mathrm{H}, \mathrm{d}, 4.4, \mathrm{H}-19 \alpha), 0.07$ (1H, d, 4.5, H-19ß);

${ }^{13} \mathrm{C}$ NMR (150 MHz, CDCl 3 ; $\delta$ (ppm)): 209.61 (qC, C-20), 153.08 (qC, C-4), $101.59\left(\mathrm{CH}_{2}\right.$, C-29), $72.04(\mathrm{CH}, \mathrm{C}-16), 70.66$ (CH, C-17), 63.65 (CH, C-3), 48.51 (qC, C-14), 47.77 (qC, C-13), $47.28(\mathrm{CH}, \mathrm{C}-8), 45.93\left(\mathrm{CH}_{2}, \mathrm{C}-15\right), 44.34(\mathrm{CH}, \mathrm{C}-5), 34.39\left(\mathrm{CH}_{3}, \mathrm{C}-31 / 32\right), 34.27\left(\mathrm{CH}_{2}, \mathrm{C}-2\right)$, 32.44 (qC, C-10), $31.90\left(\mathrm{CH}_{2}, \mathrm{C}-1\right), 31.54\left(\mathrm{CH}_{2}, \mathrm{C}-12\right), 31.37\left(\mathrm{CH}_{3}, \mathrm{C}-21\right), 27.81\left(\mathrm{CH}_{2}, \mathrm{C}-19\right)$, $26.87\left(\mathrm{CH}_{2}, \mathrm{C}-11\right), 25.52\left(\mathrm{CH}_{2}, \mathrm{C}-7\right), 23.68\left(\mathrm{CH}_{2}, \mathrm{C}-6\right), 22.85(\mathrm{qC}, \mathrm{C}-9), 20.75\left(\mathrm{CH}_{3}, \mathrm{C}-18\right)$, $20.71\left(\mathrm{CH}_{3}, \mathrm{C}-28\right)$.

+ESI-QqTOF-MS ( $m / z)$ : $372.2963[\mathrm{M}+\mathrm{H}]^{+}$(calcd for $\mathrm{C}_{24} \mathrm{H}_{38} \mathrm{NO}_{2}{ }^{+}: 372.2903$ ).

Cyclomicrobuxine (18): light yellow powder; ${ }^{1} \mathrm{H} \mathrm{NMR}\left(600 \mathrm{MHz}, \mathrm{CDCl}_{3} ; \delta\right.$ (ppm), intensity, mult., J (Hz)): 5.07 (1H, s, H-29 $\alpha), 4.90$ (1H, m, H-16), 4.75 (1H, s, H-29ß), 3.02 (1H, d, 6.7, H-17), 2.96 (1H, m, H-3), 2.49 (6H, br s, H-31/32), 2.19 (1H, m, H-11 $\alpha), 2.16(3 \mathrm{H}$, s, H-21), 2.09 (1H, m, H-5), $2.06(1 \mathrm{H}, \mathrm{m}, \mathrm{H}-2 \alpha), 2.02(1 \mathrm{H}, \mathrm{m}, \mathrm{H}-12 \alpha), 1.94(1 \mathrm{H}, \mathrm{m}, \mathrm{H}-15 \alpha)$, $1.72(1 \mathrm{H}, \mathrm{m}, \mathrm{H}-12 \beta), 1.57(1 \mathrm{H}, \mathrm{m}, \mathrm{H}-6 \alpha), 1.54(1 \mathrm{H}, \mathrm{dd}, 12.1,4.7, \mathrm{H}-8), 1.44(1 \mathrm{H}, \mathrm{m}, \mathrm{H}-15 \beta)$, $1.43(1 \mathrm{H}, \mathrm{m}, \mathrm{H}-1 \alpha), 1.42(1 \mathrm{H}, \mathrm{m}, \mathrm{H}-2 \beta), 1.36(1 \mathrm{H}, \mathrm{m}, \mathrm{H}-7 \alpha), 1.27(1 \mathrm{H}, \mathrm{m}, \mathrm{H}-1 \beta), 1.26(1 \mathrm{H}, \mathrm{m}$, H-11ß), 1.21 (3H, s, H-28), 1.19 (1H, m, H-7 $\beta), 1.02(1 \mathrm{H}, \mathrm{m}, \mathrm{H}-6 \beta), 0.92(3 \mathrm{H}, \mathrm{s}, \mathrm{H}-18), 0.33$ $(1 \mathrm{H}, \mathrm{d}, 4.5, \mathrm{H}-19 \alpha), 0.08(1 \mathrm{H}, \mathrm{d}, 4.5, \mathrm{H}-19 \beta)$;

${ }^{13} \mathrm{C}$ NMR (150 MHz, $\left.\mathrm{CDCl}_{3} ; \delta(\mathrm{ppm})\right): 209.53$ (qC, C-20), 152.64 (qC, C-4), $104.62\left(\mathrm{CH}_{2}\right.$, C-29), 72.08 (CH, C-16), $70.63(\mathrm{CH}, \mathrm{C}-17), 68.64(\mathrm{CH}, \mathrm{C}-3), 48.49$ (qC, C-14), 47.76 (qC, C-13), 47.29 (CH, C-8), $45.94\left(\mathrm{CH}_{2}, \mathrm{C}-15\right), 44.52(\mathrm{CH}, \mathrm{C}-5), 42.47\left(\mathrm{CH}_{3}, \mathrm{C}-31 / 32\right), 32.08(\mathrm{qC}, \mathrm{C}-10)$, $31.93\left(\mathrm{CH}_{2}, \mathrm{C}-1\right), 31.51\left(\mathrm{CH}_{2}, \mathrm{C}-12\right), 31.37\left(\mathrm{CH}_{3}, \mathrm{C}-21\right), 27.10\left(\mathrm{CH}_{2}, \mathrm{C}-2\right), 27.76\left(\mathrm{CH}_{2}, \mathrm{C}-19\right)$, $26.90\left(\mathrm{CH}_{2}, \mathrm{C}-11\right), 25.53\left(\mathrm{CH}_{2}, \mathrm{C}-7\right), 23.86\left(\mathrm{CH}_{2}, \mathrm{C}-6\right), 22.78(\mathrm{qC}, \mathrm{C}-9), 20.75\left(\mathrm{CH}_{3}, \mathrm{C}-18\right)$, $20.74\left(\mathrm{CH}_{3}, \mathrm{C}-28\right)$.

+ESI-QqTOF-MS $(m / z): 386.3094[\mathrm{M}+\mathrm{H}]^{+}$(calcd for $\mathrm{C}_{25} \mathrm{H}_{40} \mathrm{NO}_{2}{ }^{+}$: 386.3059). 
Irehine (19): light yellow powder; ${ }^{1} \mathrm{H} \mathrm{NMR}\left(600 \mathrm{MHz}, \mathrm{CD}_{3} \mathrm{OD} ; \delta\right.$ (ppm), intensity, mult., J (Hz)): $5.34(1 \mathrm{H}, \mathrm{m}, \mathrm{H}-6), 3.40(1 \mathrm{H}, \mathrm{m}, \mathrm{H}-3), 3.35$ (1H, m, H-20), 2.87 (3H, s, H-33/34), $2.70(3 \mathrm{H}, \mathrm{s}, \mathrm{H}-33 / 34), 2.24(1 \mathrm{H}, \mathrm{m}, \mathrm{H}-4 \alpha), 2.21(1 \mathrm{H}, \mathrm{m}, \mathrm{H}-4 \beta), 2.04(1 \mathrm{H}, \mathrm{m}, \mathrm{H}-7 \alpha), 2.00$ $(1 \mathrm{H}, \mathrm{m}, \mathrm{H}-7 \beta), 1.98(1 \mathrm{H}, \mathrm{m}, \mathrm{H}-12 \alpha), 1.91(1 \mathrm{H}, \mathrm{m}, \mathrm{H}-16 \alpha), 1.88(1 \mathrm{H}, \mathrm{m}, \mathrm{H}-1 \alpha), 1.81(1 \mathrm{H}, \mathrm{m}$,

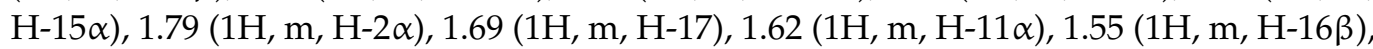
$1.54(1 \mathrm{H}, \mathrm{m}, \mathrm{H}-8), 1.51(1 \mathrm{H}, \mathrm{m}, \mathrm{H}-11 \beta), 1.49(1 \mathrm{H}, \mathrm{m}, \mathrm{H}-2 \beta), 1.33(1 \mathrm{H}, \mathrm{m}, \mathrm{H}-12 \beta), 1.33(3 \mathrm{H}, \mathrm{d}$, 6.6, H-21), $1.31(1 \mathrm{H}, \mathrm{m}, \mathrm{H}-15 \beta), 1.20(1 \mathrm{H}, \mathrm{m}, \mathrm{H}-14), 1.08$ (1H, $\mathrm{m}, \mathrm{H}-1 \beta), 1.04(3 \mathrm{H}, \mathrm{s}, \mathrm{H}-19)$, $1.00(1 \mathrm{H}, \mathrm{m}, \mathrm{H}-9), 0.79(3 \mathrm{H}, \mathrm{s}, \mathrm{H}-18)$;

${ }^{13} \mathrm{C}$ NMR $\left(150 \mathrm{MHz}, \mathrm{CD}_{3} \mathrm{OD} ; \delta(\mathrm{ppm})\right): 142.33(\mathrm{qC}, \mathrm{C}-5), 122.12(\mathrm{CH}, \mathrm{C}-6), 72.36(\mathrm{CH}$, C-3), $67.01(\mathrm{CH}, \mathrm{C}-20), 57.58(\mathrm{CH}, \mathrm{C}-14), 53.13(\mathrm{CH}, \mathrm{C}-17), 51.41(\mathrm{CH}, \mathrm{C}-9), 43.99$ (qC, C-13), $43.36\left(\mathrm{CH}_{3}, \mathrm{C}-33 / 34\right), 42.95\left(\mathrm{CH}_{2}, \mathrm{C}-4\right), 38.51\left(\mathrm{CH}_{2}, \mathrm{C}-1\right), 37.64(\mathrm{qC}, \mathrm{C}-10), 35.73\left(\mathrm{CH}_{3}\right.$, $\mathrm{C}-33 / 34), 33.08(\mathrm{CH}, \mathrm{C}-8), 32.81\left(\mathrm{CH}_{2}, \mathrm{C}-7\right), 32.25\left(\mathrm{CH}_{2}, \mathrm{C}-2\right), 29.36\left(\mathrm{CH}_{2}, \mathrm{C}-12\right), 26.83\left(\mathrm{CH}_{2}\right.$, $\mathrm{C}-16), 25.28\left(\mathrm{CH}_{2}, \mathrm{C}-15\right), 22.04\left(\mathrm{CH}_{2}, \mathrm{C}-11\right), 19.82\left(\mathrm{CH}_{3}, \mathrm{C}-19\right), 12.26\left(\mathrm{CH}_{3}, \mathrm{C}-18\right), 11.96$ $\left(\mathrm{CH}_{3}, \mathrm{C}-21\right)$.

+ESI-QqTOF-MS ( $m / z): 346.3215[\mathrm{M}+\mathrm{H}]^{+}$(calcd for $\left.\mathrm{C}_{23} \mathrm{H}_{40} \mathrm{NO}^{+}: 346.3110\right)$.

16- $\alpha$-hydroxybuxaminone (20): light yellow powder; ${ }^{1} \mathrm{H} \mathrm{NMR}\left(600 \mathrm{MHz}, \mathrm{CDCl}_{3}\right.$; $\delta(\mathrm{ppm})$, intensity, mult., J (Hz)): $5.99(1 \mathrm{H}, \mathrm{s}, \mathrm{H}-19), 5.63(1 \mathrm{H}, \mathrm{br} \mathrm{s}, \mathrm{H}-11), 4.93(1 \mathrm{H}, \mathrm{m}$, H-16), 3.02 (1H, dd, 12.9, 4.0, H-3), 2.99 (1H, d, 6.6, H-17), 2.94 (3H, s, H-31/32), 2.79 (3H, s, $\mathrm{H}-31 / 32), 2.52(1 \mathrm{H}, \mathrm{d}, 18.4, \mathrm{H}-12 \alpha), 2.43(1 \mathrm{H}, \mathrm{m}, \mathrm{H}-1 \alpha), 2.24(1 \mathrm{H}, \mathrm{m}, \mathrm{H}-1 \beta), 2.20(1 \mathrm{H}, \mathrm{m}$, H-6 $\alpha), 2.17$ (3H, s, H-21), $2.12(1 \mathrm{H}, \mathrm{m}, \mathrm{H}-12 \beta), 2.07$ (1H, m, H-5), 2.05 (1H, m, H-15 $\alpha), 2.02$ $(1 \mathrm{H}, \mathrm{m}, \mathrm{H}-8), 1.95(1 \mathrm{H}, \mathrm{m}, \mathrm{H}-2 \alpha), 1.83(1 \mathrm{H}, \mathrm{m}, \mathrm{H}-2 \beta), 1.53(1 \mathrm{H}, \mathrm{m}, \mathrm{H}-7 \alpha), 1.49(1 \mathrm{H}, \mathrm{dd}, 13.8$, 1.9, H-15ß), $1.40(1 \mathrm{H}, \mathrm{m}, \mathrm{H}-6 \beta), 1.35$ (3H, s, H-29), $1.31(1 \mathrm{H}, \mathrm{m}, \mathrm{H}-7 \beta), 0.96(3 \mathrm{H}, \mathrm{s}, \mathrm{H}-30)$, 0.95 (3H, s, H-28), 0.68 (3H, s, H-18);

${ }^{13} \mathrm{C}$ NMR (150 MHz, CDCl $; \delta$ (ppm)): 209.07 (qC, C-20), 138.03 (qC, C-9), 131.99 (qC, C-10), 131.05 (CH, C-19), $129.94(\mathrm{CH}, \mathrm{C}-11), 76.34(\mathrm{CH}, \mathrm{C}-3), 71.76(\mathrm{CH}, \mathrm{C}-16), 69.03(\mathrm{CH}$, C-17), 51.77 ( $\mathrm{CH}, \mathrm{C}-5), 48.94(\mathrm{CH}, \mathrm{C}-8), 48.15(\mathrm{qC}, \mathrm{C}-14), 47.12\left(\mathrm{CH}_{3}, \mathrm{C}-31 / 32\right), 45.78(\mathrm{qC}$, $\mathrm{C}-13), 43.66\left(\mathrm{CH}_{2}, \mathrm{C}-15\right), 41.41$ (qC, C-4), $40.47\left(\mathrm{CH}_{3}, \mathrm{C}-31 / 32\right), 39.41\left(\mathrm{CH}_{2}, \mathrm{C}-1\right), 37.36$ $\left(\mathrm{CH}_{2}, \mathrm{C}-12\right), 31.23\left(\mathrm{CH}_{3}, \mathrm{C}-21\right), 29.53\left(\mathrm{CH}_{2}, \mathrm{C}-6\right), 25.31\left(\mathrm{CH}_{2}, \mathrm{C}-7\right), 24.24\left(\mathrm{CH}_{3}, \mathrm{C}-29\right), 23.45$ $\left(\mathrm{CH}_{2}, \mathrm{C}-2\right), 18.45\left(\mathrm{CH}_{3}, \mathrm{C}-18\right), 18.36\left(\mathrm{CH}_{3}, \mathrm{C}-28\right), 15.13\left(\mathrm{CH}_{3}, \mathrm{C}-30\right)$.

+ESI-QqTOF-MS $(m / z)$ : $400.3287[\mathrm{M}+\mathrm{H}]^{+}$(calcd for $\mathrm{C}_{26} \mathrm{H}_{42} \mathrm{NO}_{2}{ }^{+}: 400.3216$ ).

$\mathrm{N}_{20}$-acetylbuxamine-E (21): colorless gum; ${ }^{1} \mathrm{H}$ NMR $\left(600 \mathrm{MHz}, \mathrm{CD}_{3} \mathrm{OD} ; \delta(\mathrm{ppm})\right.$, intensity, mult., J (Hz)): $6.05(1 \mathrm{H}, \mathrm{s}, \mathrm{H}-19), 5.61(1 \mathrm{H}, \mathrm{br} \mathrm{s}, \mathrm{H}-11), 3.92(1 \mathrm{H}, \mathrm{m}, \mathrm{H}-20), 3.29$ $(1 \mathrm{H}, \mathrm{m}, \mathrm{H}-3), 2.97(3 \mathrm{H}, \mathrm{s}, \mathrm{H}-31 / 32), 2.79(3 \mathrm{H}, \mathrm{s}, \mathrm{H}-31 / 32), 2.41(1 \mathrm{H}, \mathrm{m}, \mathrm{H}-1 \alpha), 2.27(1 \mathrm{H}, \mathrm{m}$, H-1 $\beta), 2.21(1 \mathrm{H}, \mathrm{m}, \mathrm{H}-5), 2.21(1 \mathrm{H}, \mathrm{m}, \mathrm{H}-7 \alpha), 2.18(1 \mathrm{H}, \mathrm{m}, \mathrm{H}-12 \alpha), 2.14(1 \mathrm{H}, \mathrm{m}, \mathrm{H}-8), 2.08$

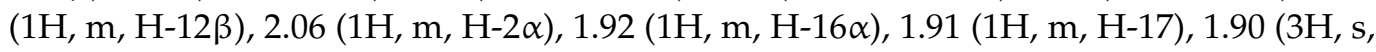
Ac- $\left.\mathrm{CH}_{3}\right), 1.84(1 \mathrm{H}, \mathrm{m}, \mathrm{H}-2 \beta), 1.59(1 \mathrm{H}, \mathrm{m}, \mathrm{H}-6 \alpha), 1.50(1 \mathrm{H}, \mathrm{dd}, 12.0,6.2, \mathrm{H}-15 \alpha), 1.45(1 \mathrm{H}$, $\mathrm{m}, \mathrm{H}-15 \beta), 1.42(1 \mathrm{H}, \mathrm{m}, \mathrm{H}-16 \beta), 1.32(1 \mathrm{H}, \mathrm{m}, \mathrm{H}-6 \beta), 1.29(1 \mathrm{H}, \mathrm{m}, \mathrm{H}-7 \beta), 1.20(3 \mathrm{H}, \mathrm{s}, \mathrm{H}-29)$, $1.10(3 \mathrm{H}, \mathrm{d}, 6.4, \mathrm{H}-21), 0.91(3 \mathrm{H}, \mathrm{s}, \mathrm{H}-30), 0.81$ (3H, s, H-18), 0.74 (3H, s, H-28);

${ }^{13} \mathrm{C}$ NMR $\left(150 \mathrm{MHz}, \mathrm{CD}_{3} \mathrm{OD} ; \delta(\mathrm{ppm})\right): 171.86$ (qC, Ac-CO), 139.24 (qC, C-9), 133.06 (qC, C-10), 131.85 (CH, C-19), $131.62(\mathrm{CH}, \mathrm{C}-11), 77.22(\mathrm{CH}, \mathrm{C}-3), 52.26(\mathrm{CH}, \mathrm{C}-17), 52.04$ (CH, C-5), 50.73 (CH, C-8), 49.84 (qC, C-14), $49.55(\mathrm{CH}, \mathrm{C}-20), 47.24\left(\mathrm{CH}_{3}, \mathrm{C}-31 / 32\right), 44.22$ (qC, C-13), 41.93 (qC, C-4), $40.87\left(\mathrm{CH}_{3}, \mathrm{C}-31 / 32\right), 40.08\left(\mathrm{CH}_{2}, \mathrm{C}-1\right), 39.21\left(\mathrm{CH}_{2}, \mathrm{C}-12\right), 33.88$ $\left(\mathrm{CH}_{2}, \mathrm{C}-15\right), 30.73\left(\mathrm{CH}_{2}, \mathrm{C}-7\right), 27.45\left(\mathrm{CH}_{2}, \mathrm{C}-16\right), 26.27\left(\mathrm{CH}_{2}, \mathrm{C}-6\right), 24.22\left(\mathrm{CH}_{2}, \mathrm{C}-2\right), 23.78$ $\left(\mathrm{CH}_{3}, \mathrm{C}-29\right), 22.67\left(\mathrm{CH}_{3}, \mathrm{Ac}-\mathrm{CH}_{3}\right), 21.18\left(\mathrm{CH}_{3}, \mathrm{C}-21\right), 17.38\left(\mathrm{CH}_{3}, \mathrm{C}-28\right), 16.13\left(\mathrm{CH}_{3}, \mathrm{C}-18\right)$, $15.07\left(\mathrm{CH}_{3}, \mathrm{C}-30\right)$.

+ESI-QqTOF-MS $(m / z): 427.3719[\mathrm{M}+\mathrm{H}]^{+}, 214.1903[\mathrm{M}+2 \mathrm{H}]^{2+}\left(\right.$ calcd for $\mathrm{C}_{28} \mathrm{H}_{47} \mathrm{~N}_{2} \mathrm{O}^{+}$: 427.3688, for $\left.\mathrm{C}_{28} \mathrm{H}_{48} \mathrm{~N}_{2} \mathrm{O}^{2+}: 214.1884\right)$; MS/MS $(m / z): 382\left[\mathrm{M}-\left(\mathrm{CH}_{3}\right)_{2} \mathrm{NH}\right]^{+}, 340[382-$ $\left.\mathrm{CH}_{2}=\mathrm{CO}\right]^{+}, 323\left[340-\mathrm{NH}_{3}\right]^{+}$.

N-benzoyl-O-acetylbuxodienine-E (22): white powder; UV (MeOH; $\lambda \max ,(\log \varepsilon)$ ): 237 (4.54), 245 (4.53), 253 (4.35); ${ }^{1} \mathrm{H}$ NMR (600 MHz, $\mathrm{CD}_{3} \mathrm{OD} ; \delta$ (ppm), intensity, mult., J (Hz)): $7.79\left(2 \mathrm{H}, \mathrm{m}, \mathrm{H}-2^{\prime} / 6^{\prime}\right), 7.51\left(1 \mathrm{H}, \mathrm{m}, \mathrm{H}-4^{\prime}\right), 7.45\left(2 \mathrm{H}, \mathrm{m}, \mathrm{H}-3^{\prime} / 5^{\prime}\right), 5.94(1 \mathrm{H}, \mathrm{br} \mathrm{s}, \mathrm{H}-19)$, $5.55(1 \mathrm{H}$, br m, H-11), 5.06 (1H, ddd, 9.0, 6.6, 1.4, H-16), $4.43(1 \mathrm{H}, \mathrm{m}, \mathrm{H}-20), 2.37(1 \mathrm{H}, \mathrm{m}$, H-17), 2.35 (1H, m, H-12 $\alpha), 2.30$ (6H, s, H-31/32), 2.30 (1H, m, H-1 $\alpha), 2.22(1 \mathrm{H}, \mathrm{m}, \mathrm{H}-3)$, $2.15(1 \mathrm{H}, \mathrm{m}, \mathrm{H}-6 \alpha), 2.13(1 \mathrm{H}, \mathrm{m}, \mathrm{H}-1 \beta), 2.13(1 \mathrm{H}, \mathrm{m}, \mathrm{H}-12 \beta), 2.13(1 \mathrm{H}, \mathrm{m}, \mathrm{H}-15 \alpha), 2.10(1 \mathrm{H}$, 
m, H-8), $\left.2.01(1 \mathrm{H}, \mathrm{m}, \mathrm{H}-5), 1.80(1 \mathrm{H}, \mathrm{dd}, 12.0,3.4, \mathrm{H}-2 \alpha), 1.62\left(3 \mathrm{H}, \mathrm{s}, \mathrm{Ac}^{-C H}\right)_{3}\right), 1.55(1 \mathrm{H}$,

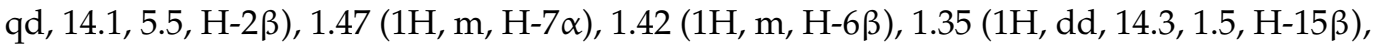
$1.30(1 \mathrm{H}, \mathrm{m}, \mathrm{H}-7 \beta), 1.28$ (3H, d, 6.7, H-21), 1.03 (3H, s, H-29), 0.92 (3H, s, H-18), 0.89 (3H, s, $\mathrm{H}-28), 0.74$ (3H, s, H-30);

${ }^{13} \mathrm{C}$ NMR (150 MHz, CD 3 OD; $\left.\delta(\mathrm{ppm})\right): 172.39$ (qC, Ac-CO), 168.63 (qC, OCNH), 139.68 (qC, C-9), 137.46 (qC, C-10), 135.84 (qC, C-1'), $132.55\left(\mathrm{CH}, \mathrm{C}-4^{\prime}\right), 129.65$ (CH, C-19), $129.46\left(\mathrm{CH}, \mathrm{C}-3^{\prime} / 5^{\prime}\right), 129.13(\mathrm{CH}, \mathrm{C}-11), 128.28\left(\mathrm{CH}, \mathrm{C}-2^{\prime} / 6^{\prime}\right), 80.75(\mathrm{CH}, \mathrm{C}-16), 73.14(\mathrm{CH}$, C-3), 57.90 (CH, C-17), 53.15 (CH, C-5), 50.43 (CH, C-8), 48.31 (qC, C-14), 48.17 (CH, C-20), 44.86 (qC, C-13), $44.79\left(\mathrm{CH}_{3}, \mathrm{C}-31 / 32\right), 44.12$ (qC, C-4), $43.79\left(\mathrm{CH}_{2}, \mathrm{C}-15\right), 42.26\left(\mathrm{CH}_{2}\right.$, $\mathrm{C}-1), 38.88\left(\mathrm{CH}_{2}, \mathrm{C}-12\right), 31.18\left(\mathrm{CH}_{2}, \mathrm{C}-6\right), 26.63\left(\mathrm{CH}_{2}, \mathrm{C}-7\right), 25.29\left(\mathrm{CH}_{3}, \mathrm{C}-29\right), 24.19\left(\mathrm{CH}_{2}\right.$, $\mathrm{C}-2), 20.96\left(\mathrm{CH}_{3}, \mathrm{Ac}-\mathrm{CH}_{3}\right), 20.68\left(\mathrm{CH}_{3}, \mathrm{C}-21\right), 17.89\left(\mathrm{CH}_{3}, \mathrm{C}-28\right), 17.02\left(\mathrm{CH}_{3}, \mathrm{C}-18\right), 15.46$ $\left(\mathrm{CH}_{3}, \mathrm{C}-30\right)$.

+ESI-QqTOF-MS $(m / z): 547.3977[\mathrm{M}+\mathrm{H}]^{+}, 274.2040[\mathrm{M}+2 \mathrm{H}]^{2+}\left(\right.$ calcd for $\mathrm{C}_{35} \mathrm{H}_{51} \mathrm{~N}_{2} \mathrm{O}_{3}{ }^{+}$: 547.3900, for $\mathrm{C}_{35} \mathrm{H}_{52} \mathrm{~N}_{2} \mathrm{O}_{3}{ }^{2+}:$ 274.1989); MS/MS (m/z): $442\left[\mathrm{M}-\left(\left(\mathrm{CH}_{3}\right)_{2} \mathrm{NH}\right)-\left(\mathrm{CH}_{3} \mathrm{COOH}\right)\right]^{+}$, $321\left[442-\mathrm{C}_{7} \mathrm{H}_{7} \mathrm{NO}\right]^{+}, 148\left[\mathrm{C}_{9} \mathrm{H}_{10} \mathrm{NO}\right]^{+}, 105\left[\mathrm{C}_{7} \mathrm{H}_{5} \mathrm{O}\right]^{+}$.

N-benzoyl-O-acetylbuxadine-E (23): white powder; UV (MeOH; $\lambda \max ,(\log \varepsilon)): 225$ (4.01); ${ }^{1} \mathrm{H}$ NMR and ${ }^{13} \mathrm{C}$ NMR $\left(600 / 150 \mathrm{MHz}, \mathrm{CD}_{3} \mathrm{OD}\right)$ see Table 3;

+ESI-QqTOF-MS $(m / z): 1093.7853[2 \mathrm{M}+\mathrm{H}]^{+}, 547.3917[\mathrm{M}+\mathrm{H}]^{+}, 274.2038[\mathrm{M}+$ $2 \mathrm{H}]^{2+}$ (calcd for $\mathrm{C}_{35} \mathrm{H}_{51} \mathrm{~N}_{2} \mathrm{O}_{3}{ }^{+}$: 547.3900, for $\mathrm{C}_{35} \mathrm{H}_{52} \mathrm{~N}_{2} \mathrm{O}_{3}{ }^{2+}$ : 274.1989); MS/MS (m/z): $442\left[\mathrm{M}-\left(\left(\mathrm{CH}_{3}\right)_{2} \mathrm{NH}\right)-\left(\mathrm{CH}_{3} \mathrm{COOH}\right)\right]^{+}, 321\left[442-\mathrm{C}_{7} \mathrm{H}_{7} \mathrm{NO}\right]^{+}, 148\left[\mathrm{C}_{9} \mathrm{H}_{10} \mathrm{NO}\right]^{+}, 105\left[\mathrm{C}_{7} \mathrm{H}_{5} \mathrm{O}\right]^{+}$ (fragmentation pathway reported in Figure S122, Supplementary Materials).

$\mathrm{N}_{20}$-acetylbuxadine-G (24): colorless gum; ${ }^{1} \mathrm{H}$ NMR and ${ }^{13} \mathrm{C}$ NMR $(600 / 150 \mathrm{MHz}$, $\mathrm{CDCl}_{3}$ ) see Table 3;

+ESI-QqTOF-MS $(m / z): 413.0273[\mathrm{M}+\mathrm{H}]^{+}, 207.4721[\mathrm{M}+2 \mathrm{H}]^{2+}\left(\right.$ calcd for $\mathrm{C}_{27} \mathrm{H}_{45} \mathrm{~N}_{2} \mathrm{O}^{+}$: 413.3532, for $\mathrm{C}_{27} \mathrm{H}_{46} \mathrm{~N}_{2} \mathrm{O}^{2+}$ : 207.1805); $\mathrm{MS} / \mathrm{MS}(\mathrm{m} / \mathrm{z}): 382\left[\mathrm{M}-\mathrm{CH}_{3} \mathrm{NH}_{2}\right]^{+}, 323\left[382-\mathrm{CH}_{3}\right.$ $\left.\mathrm{CONH}_{2}\right]^{+}$.

17,20-dihydroxybuxadine-M (25): colorless gum; ${ }^{1} \mathrm{H}$ NMR and ${ }^{13} \mathrm{C}$ NMR $(600 / 150 \mathrm{MHz}$, $\mathrm{CDCl}_{3}$ ) see Table 3;

+ESI-QqTOF-MS $(\mathrm{m} / z)$ : $388.3272[\mathrm{M}+\mathrm{H}]^{+}$(calcd for $\mathrm{C}_{25} \mathrm{H}_{42} \mathrm{NO}_{2}{ }^{+}$: 388.3216); MS/MS $(m / z): 339\left[\mathrm{M}-\left(\mathrm{CH}_{3} \mathrm{NH}_{2}\right)-\left(\mathrm{H}_{2} \mathrm{O}\right)\right]^{+}, 321\left[339-\mathrm{H}_{2} \mathrm{O}\right]^{+}$.

\subsection{In Vitro Bioassays}

In vitro assays for the bioactivity of the isolated Buxus-alkaloids against Tbr (bloodstream trypomastigotes, STIB 900 strain), Trypanosoma cruzi (Tc) (amastigotes, Tulahuen C4 strain), Leishmania donovani (Ldo) (amastigotes, MHOM-ET-67/L82 strain) and Pf (intraerythrocytic forms, NF54 strain), and cytotoxicity tests against mammalian cells (L6-cell line from rat-skeletal myoblasts), were performed at the Swiss Tropical and Public Health Institute (Swiss TPH, Basel, Switzerland) according to established standard protocols [36]. The alkaloids were inactive against $T c$ and $L d o$ at the concentration tested. Such a pattern of activity was also observed in other studies [37].

\section{Conclusions}

The present study provides an extended chemical analysis of alkaloids isolated from a B. sempervirens L. leaf extract. The structure of eight new natural products could be elucidated and the NMR data of already known Buxus-alkaloids are reported here in full for the first time. Moreover, cyclomicrophyllidine-A (6) was primarily obtained from the leaves of $B$. sempervirens L. Several of the isolated compounds displayed promising and selective in vitro activity against the protozoan parasites $P f$ and $\mathrm{Tbr}$. Of the 25 structures isolated, five compounds $(3,4,6-8)$ showed auspicious antiplasmodial activity with $\mathrm{IC}_{50}$ values of $<1.0 \mu \mathrm{M}$. Against the causative agent of HAT, compound 2, 6, 8, and 24 exhibited interesting $\mathrm{IC}_{50}$ values in the range of 1.1-1.5 $\mu \mathrm{M}$. The new natural product O-benzoylcycloprotobuxoline-D (8) was the most active substance in both cases. The highest selectivity was reached by cyclomicrophyllidine-B (7) (SI 145 for Pf) and cyclomicrophylline-A (5) (SI 42 for Tbr), respectively. Accordingly, these Buxus-alkaloids have the potential to serve 
as antiprotozoal lead structures. Structure-activity relationship studies are in progress in order to identify structural functionalities that increase activity and reduce toxicity. In conclusion, the work presented here may represent an important first step in the development of this new class of antiprotozoal drugs against malaria and HAT.

Supplementary Materials: The following are available online at https: / www.mdpi.com/article / 10.3390 / antibiotics10060696/s1, the ${ }^{1} \mathrm{H}$ and ${ }^{13} \mathrm{C}$ NMR spectra of all the isolated compounds are provided as Supplementary Figures S1-S4, S8-S11, S21-S24, S31-S38, S42-S45, S54-S57, S63-S70, S74-S77, S82-S118, S124-S127, S137-S140, and S149-S152. For the new natural products, additional LC/MS chromatograms, UV, and 2D NMR spectra, as well as key correlations of HMBC and COSY spectra, are supplied as Supplementary Figures S5-S7, S12-S20, S25-S30, S39-S41, S46-S53, S58-S62, S71-S73, S78-S81, S119-S123, S128-S136, S141-S148, and S153-158.

Author Contributions: Conceptualization, T.J.S.; investigation, L.U.S. and M.K.; resources, T.J.S. and P.M.; data curation, L.U.S., T.J.S. and M.K.; writing-original draft preparation, L.U.S. and T.J.S.; writing-review and editing, L.U.S., T.J.S., M.K. and P.M.; supervision, T.J.S.; project administration, T.J.S. and P.M.; funding acquisition, L.U.S. and T.J.S. All authors have read and agreed to the published version of the manuscript.

Funding: This research received external funding in the form of a doctoral fellowship for L. U. Szabó from Apothekerstiftung Westfalen-Lippe.

Institutional Review Board Statement: Not applicable.

Informed Consent Statement: Not applicable.

Data Availability Statement: Data is contained within the article and Supplementary Materials. The underlying raw data are available from the corresponding author on request.

Acknowledgments: L.U.S. is most grateful for financial support by Apothekerstiftung WestfalenLippe in the form of a doctoral fellowship. The authors thank C. O. Nnadi (Münster) for isolation of compound 23. Thanks are due to J. Sendker and F. M. Jürgens (Münster) for support with the UHPLC/+ESI-QqTOF-MS/MS analyses, to J. Köhler (Münster) for NMR measurements, and to K. Possart (Münster) for support with the spectrophotometer. We thank M. Cal, S. Keller-Maerki and R. Rocchetti for assistance with the parasite and cytotoxicity assays. This work is part of the activities of the Research Network Natural Products against Neglected Diseases (ResNet NPND, see www.resnetnpnd.org).

Conflicts of Interest: The authors declare no conflict of interest.

\section{References}

1. Neves, J.M.; Matos, C.; Moutinho, C.; Queiroz, G.; Gomes, L.R. Ethnopharmacological notes about ancient uses of medicinal plants in Trás-os-Montes (northern of Portugal). J. Ethnopharmacol. 2009, 124, 270-283. [CrossRef] [PubMed]

2. Leporatti, M.L.; Pavesi, A.; Posocco, E. Phytotherapy in the Valnerina Marche (Central Italy). J. Ethnopharmacol. 1985, 14, 53-63. [CrossRef]

3. Atta-ur-Rahman; Choudhary, M.I. Diterpenoid and steroidal alkaloids. Nat. Prod. Rep. 1999, 16, 619-635. [CrossRef]

4. Ata, A.; Andersh, B.J. Chapter 3 Buxus Steroidal Alkaloids: Chemistry and Biology; The Alkaloids: Chemistry and Biology; Academic Press: London, UK, 2008; pp. 191-213.

5. Yan, Y.-X.; Sun, Y.; Li, Z.-R.; Zhou, L.; Qiu, M.-H. Chemistry and Biological Activities of Buxus Alkaloids. CBC 2011, 7, 47-64. [CrossRef]

6. Althaus, J.B.; Jerz, G.; Winterhalter, P.; Kaiser, M.; Brun, R.; Schmidt, T.J. Antiprotozoal activity of Buxus sempervirens and activity-guided isolation of O-tigloylcyclovirobuxeine-B as the main constituent active against Plasmodium falciparum. Molecules 2014, 19, 6184-6201. [CrossRef] [PubMed]

7. Cai, S.; Risinger, A.L.; Nair, S.; Peng, J.; Anderson, T.J.C.; Du, L.; Powell, D.R.; Mooberry, S.L.; Cichewicz, R.H. Identification of Compounds with Efficacy against Malaria Parasites from Common North American Plants. J. Nat. Prod. 2016, 79, 490-498. [CrossRef]

8. $\quad$ Flittner, D.; Kaiser, M.; Mäser, P.; Lopes, N.P.; Schmidt, T.J. The Alkaloid-Enriched Fraction of Pachysandra terminalis (Buxaceae) Shows Prominent Activity against Trypanosoma brucei rhodesiense. Molecules 2021, 26, 591. [CrossRef] [PubMed]

9. Nnadi, C.O.; Althaus, J.B.; Nwodo, N.J.; Schmidt, T.J. A 3D-QSAR Study on the Antitrypanosomal and Cytotoxic Activities of Steroid Alkaloids by Comparative Molecular Field Analysis. Molecules 2018, 23, 1113. [CrossRef] [PubMed]

10. Kupchan, S.M.; Kennedy, R.M.; Schleigh, W.R.; Ohta, G. Buxus alkaloids-XII. Tetrahedron 1967, 23, 4563-4586. [CrossRef] 
11. Szabó, L.U.; Schmidt, T.J. Target-Guided Isolation of O-tigloylcyclovirobuxeine -B from Buxus sempervirens L. by Centrifugal Partition Chromatography. Molecules 2020, 25, 4804. [CrossRef]

12. Kupchan, S.M.; Ohta, G. Buxus Alkaloids. X. 1 The Isolation and Constitution of Cyclovirobuxeine-B. J. Org. Chem. 1966, 31, 608-610. [CrossRef]

13. Nakano, T.; Terao, S. Buxus alkaloids. Part, I. The structures of three new alkaloids, cyclomicrophylline-A., B., and C., from B. microphylla Sieb. et Zucc. Tetrahedron Lett. 1964, 5, 1035-1043. [CrossRef]

14. Atta-ur-Rahman; Ahmed, D.; Asif, E.; Ahmad, S.; Sener, B.; Turkoz, S. Chemical Constituents of Buxus sempervirens. J. Nat. Prod. 1991, 54, 79-82. [CrossRef]

15. Nakano, T.; Terao, S. Buxus alkaloids. IV. Isolation and structure elucidation of eight new alkaloids, cyclomicrophylline-A, -B, and $-\mathrm{C}$, dihydrocyclomicrophylline-A and -F, cyclomicrophyllidine-A, dihydrocyclomicrophyllidine-A, and cyclomicrobuxine, from B. microphylla Sieb. et Zucc. var. suffruticosa Makino. J. Chem. Soc. Perkin Trans. 1965, 1, 4512-4537.

16. Leuthardt, F.L.G.; Glauser, G.; Baur, B. Composition of alkaloids in different box tree varieties and their uptake by the box tree moth Cydalima perspectalis. Chemoecology 2013, 23, 203-212. [CrossRef]

17. Choudhary, M.I.; Shahnaz, S.; Parveen, S.; Khalid, A.; Mesaik, M.A.; Ayatollahi, S.A.M. New cholinesterase-inhibiting triterpenoid alkaloids from Buxus hyrcana. Chem. Biodivers. 2006, 3, 1039-1052. [CrossRef] [PubMed]

18. Döpke, W.; Müller, B.; Und Jeffs, P.W. Buxarin und Buxenon, zwei neue Alkaloide aus Buxus sempervirens L. Die Pharm. Jahrg. 1966, 21, 643.

19. Ahmed, D.; Choudhary, M.I.; Turkoz, S.; Sener, B. Chemical Constituents of Buxus sempervirens. Planta Med. 1988, 54, 173-174. [PubMed]

20. Nakano, T.; Terao, S.; Saeki, Y. Buxus alkaloids. Part VII. The isolation and the constitutions of ten new alkaloids from the weak-base fractions of two species, B. microphylla Sieb. et Zucc. var. suffruticosa Makino and B. microphylla Sieb. et Zucc. var. suffruticosa Makino forma major Makino. J. Chem. Soc. C 1966, 1412.

21. Atta-ur-Rahman; Ahmed, D.; Choudhary, M.I.; Sener, B.; Turkoz, S. Alkaloids from the Leaves of Buxus sempervirens. J. Nat. Prod. 1988, 51, 783-786. [CrossRef]

22. Atta-ur-Rahman; Noor-e-ain, F.; Choudhary, M.I.; Parveen, Z.; Türköz, S.; Sener, B. New steroidal alkaloids from Buxus longifolia. J. Nat. Prod. 1997, 60, 976-981. [CrossRef]

23. Votický, Z.; Tomko, J. Alkaloids from Buxus sempervirens L. V. Configuration of buxtauine and buxpiine. Tetrahedron Lett. 1965, 6, 3579-3584. [CrossRef]

24. Kuchkova, K.I.; Voticky, Z.; Paulik, V. Buxus alkaloids. XIII. Alkaloids from Buxus sempervirens var. argentea Hort. ex. Steud. Chem. Zvesti 1976, 30, 174-178.

25. Atta-ur-Rahman; Naz, S.; Noor-e-ain, F.; Ali, R.A.; Choudhary, M.I.; Sener, B.; Turkoz, S. Alkaloids from Buxus species. Phytochemistry 1992, 31, 2933-2935. [CrossRef]

26. Loru, F.; Duval, D.; Aumelas, A.; Akeb, F.; Guédon, D.; Guedj, R. Four steroidal alkaloids from the leaves of Buxus sempervirens. Phytochemistry 2000, 54, 951-957. [CrossRef]

27. Döpke, W.; Härtel, R. N-Benzoylbuxodienin-E und N-Benzoyl-O-acetylbuxodienin-E-Zwei neue Alkaloide aus Buxus sempervirens L. Z. Chem. 1973, 13, 135-136. [CrossRef]

28. Devkota, K.P.; Lenta, B.N.; Fokou, P.A.; Sewald, N. Terpenoid alkaloids of the Buxaceae family with potential biological importance. Nat. Prod. Rep. 2008, 25, 612-630. [CrossRef] [PubMed]

29. Bienz, S.; Bigler, L.; Fox, T.; Meier, H. Spektroskopische Methoden in der Organischen Chemie; Georg Thieme Verlag: Stuttgart, Germany, 2016.

30. Meshkatalsadat, M.H.; Mollataghi, A.; Ata, A. New Triterpenoidal Alkaloids from Buxus hyrcana. Z. Naturforsch. B 2006, 61, 201-206. [CrossRef]

31. Černý, V.; Šorm, F. Chapter 8 Steroid Alkaloids: Alkaloids of Apocynaceae and Buxaceae; The Alkaloids: Chemistry and Physiology; Elsevier: Amsterdam, The Netherlands, 1967; pp. 305-426.

32. Blaschek, W.; Hager, H. (Eds.) Hagers Enzyklopädie der Arzneistoffe und Drogen. Mit 600 Tabellen; 6., neu bearb. und erg. Aufl.; Wiss. Verl.-Ges: Stuttgart, Germany, 2007.

33. Xiang, Z.-N.; Su, J.-C.; Liu, Y.-H.; Deng, B.; Zhao, N.; Pan, J.; Hu, Z.-F.; Chen, F.-H.; Cheng, B.-Y.; Chen, J.-C.; et al. Structurally diverse alkaloids from Buxus sempervirens with cardioprotective activity. Bioorg. Chem. 2021, 109, 104753. [CrossRef]

34. Theodorou, V.; Skobridis, K.; Tzakos, A.G.; Ragoussis, V. A simple method for the alkaline hydrolysis of esters. Tetrahedron Lett. 2007, 48, 8230-8233. [CrossRef]

35. Nnadi, C.O.; Nwodo, N.J.; Kaiser, M.; Brun, R.; Schmidt, T.J. Steroid Alkaloids from Holarrhena africana with Strong Activity against Trypanosoma brucei rhodesiense. Molecules 2017, 22, 1129. [CrossRef] [PubMed]

36. Bernal, F.A.; Kaiser, M.; Wünsch, B.; Schmidt, T.J. Structure-Activity Relationships of Cinnamate Ester Analogues as Potent Antiprotozoal Agents. Chem. Med. Chem. 2020, 15, 68-78. [CrossRef] [PubMed]

37. Mahmoud, A.B.; Mäser, P.; Kaiser, M.; Hamburger, M.; Khalid, S. Mining Sudanese Medicinal Plants for Antiprotozoal Agents. Front. Pharmacol. 2020, 11, 865. [CrossRef] [PubMed] 